\title{
Production, milk and plasma fatty acid profile, and nutrient utilization in Jersey cows fed flaxseed oil and corn grain with different particle size
}

\author{
V. Brossillon, ${ }^{*}$ S. F. Reis, † D. C. Moura,ł J. G. B. Galvão Jr.,§ A. S. Oliveira,ł C. Côrtes, ${ }^{* 1}$ and A. F. Brito $\dagger^{2}$ \\ *Ecole Supérieure d'Agricultures, Angers, France 49007 \\ †Department of Agriculture, Nutrition, and Food Systems, University of New Hampshire, Durham 03824 \\ †Instituto de Ciências Agrárias e Ambientais, Universidade Federal de Mato Grosso, Campus Sinop, Sinop, MT, Brazil 78557-267 \\ §Instituto Federal de Educação do Rio Grande do Norte, Ipanguaçu, RN, Brazil 59508-000
}

\begin{abstract}
We aimed to compare the effects of ground (GC) or cracked corn (CC), with or without flaxseed oil (FSO), on milk yield, milk and plasma fatty acid (FA) profile, and nutrient digestibility in Jersey cows fed diets formulated to contain similar starch concentrations. Twelve multiparous organic-certified Jersey cows averaging (mean \pm standard deviation) $455 \pm 41.9 \mathrm{~kg}$ of body weight and $152 \pm 34 \mathrm{~d}$ in milk and 4 primiparous organic-certified Jersey cows averaging (mean \pm standard deviation) $356 \pm 2.41 \mathrm{~kg}$ of body weight and $174 \pm 30$ $\mathrm{d}$ in milk in the beginning of the experiment were used. Cows were randomly assigned to treatment sequences in a replicated $4 \times 4$ Latin square design with a $2 \times 2$ factorial arrangement of treatments. Each period lasted $24 \mathrm{~d}$ with $18 \mathrm{~d}$ for diet adaptation and $6 \mathrm{~d}$ for data and sample collection. Treatments were fed as total mixed rations consisting of (dry matter basis): (1) 0\% FSO + $27.1 \%$ GC, (2) 0\% FSO + 28.3\% CC, (3) $3 \% \mathrm{FSO}+$ $27.1 \% \mathrm{GC}$, and (4) $3 \% \mathrm{FSO}+28.3 \% \mathrm{CC}$. All cows were offered $55 \%$ of the total diet dry matter as mixed grasslegume baleage and treatments averaged $20 \%$ starch. Significant FSO $\times$ corn grain particle size interactions were observed for some variables including milk concentration of lactose and proportions of cis-9,cis-12,cis- 15 18:3 in milk and plasma. The proportion of cis-9,cis12,cis-15 18:3 in milk and plasma decreased slightly when comparing GC versus CC in 0\% FSO cows, but a larger reduction was observed in 3\% FSO cows. Dry matter intake did not differ and averaged $16.1 \mathrm{~kg} / \mathrm{d}$ across diets. Feeding 3\% FSO increased yields of milk and milk fat and lactose and feed and milk $\mathrm{N}$ efficiencies, but decreased fat, true protein, and MUN concentrations and apparent total-tract digestibility of fiber. The $\Sigma$ branched-chain, $\Sigma<16 \mathrm{C}, \Sigma 16 \mathrm{C}$, and $\Sigma \mathrm{n}-6 \mathrm{FA}$
\end{abstract}

Received July 11, 2017.

Accepted November 1, 2017.

${ }^{1}$ Current address: Agrinova, Alma, Québec, Canada G8B 7S8.

${ }^{2}$ Corresponding author: andre.brito@unh.edu decreased, whereas $\Sigma 18 \mathrm{C}, \Sigma c i s-18: 1$, and $\Sigma$ trans-18:1 FA increased in $3 \%$ versus $0 \%$ FSO cows. No effect of corn particle size was observed for production and milk components. However, the apparent total-tract digestibility of starch was greater in GC than CC cows. Compared with CC, GC increased $\Sigma$ branched-chain, $\Sigma<16 \mathrm{C}, \Sigma 16 \mathrm{C}, \Sigma \mathrm{n}-6 \mathrm{FA}$, and decreased $\Sigma 18 \mathrm{C}$ and $\Sigma$ cis-18:1 FA in milk fat. Overall, results of this study are more directly applicable to dairy cows fed low starch, mixed grass-legume baleage-based diets.

Key words: milk yield, organic dairy farm, starch, vegetable oil

\section{INTRODUCTION}

Flaxseed oil (FSO) is the richest source of the essential n-3 fatty acid (FA) $\alpha$-linolenic acid (ALA; cis-9, cis12,cis-15 18:3) as ALA comprises approximately 50 to $55 \%$ of its total FA (Glasser et al., 2008; Benchaar et al., 2012). In organic-certified dairies in the United States, heifers and cows must have year-round access to the outdoors to be in compliance with the USDA National Organic Program "Livestock living conditions" regulations (section 205.239 https://www.ecfr.gov/cgi-bin/ text-idx?SID = 38fb700cb79331adaec0a1e05477134f\&mc $=$ true $\&$ node $=$ se7.3.205 $\_1239 \&$ rgn $=$ div8; accessed September 20,2017). As a result of this federally mandated rule, cows may be susceptible to cold stress during the winter months due to exposure to outside freezing temperatures, wind, snow, mud, and wet conditions, which can ultimately depress DMI and milk yield. Flaxseed oil appears to be an attractive strategy to increase energy intake and mitigate potential milk yield losses during the winter months in organic-certified dairy farms or dairies where animals are exposed to similar management conditions. However, inconsistent results have been reported in the literature in response to FSO supplementation as milk yield decreased (Chilliard et al., 2009), did not change (Loor et al., 2005; Benchaar et al., 2015), or increased (Benchaar et al., 2012, 2014). In these previous studies, cows were fed hay (Loor et 
al., 2005) or silage (Chilliard et al., 2009; Benchaar et al., 2012, 2014, 2015), but no information is available about the effect of FSO on production in dairy cows fed mixed grass-legume baleage. Oil from flaxseed may interact with the forage source in the basal diet to modulate ruminal fermentation processes, as well as DMI and milk yield responses (Glasser et al., 2008; Petit, 2010; Meignan et al., 2017), thereby reinforcing the need for research with baleage-based diets. It is important to note that mixed grass-legume baleage and haylage are more extensively used in northeastern (Hafla et al., 2016) and midwestern (Hardie et al., 2014) organic dairies than corn silage. In addition, Coblentz et al. (2016) stated that baleage is an attractive option to small- or mid-sized dairy farms because it offers several advantages when compared with dry hay, most notably reduced risk of rain damage due to less wilting time in the field.

We are also not aware of any published research that has simultaneously evaluated the effects of FSO and corn grain particle size (PS) on production, milk composition, and nutrient utilization in dairy cows. Neveu et al. (2014) reported that feeding extruded flaxseed to dairy cows increased the proportions of ALA and cis9,trans-11 18:2 in milk by 60 and $29 \%$, respectively, but the effect of cereal grain sources on these $2 \mathrm{FA}$ was not consistent. Compared with rolled barley, high-moisture corn increased milk cis-9,trans-11 $18: 2$ by $29 \%$, but did not affect ALA (Neveu et al., 2014). Recently, Lascano et al. (2016) fed soybean oil and corn grain with different starch degradability to continuous culture fermentors and observed that enhanced intake of UFA increased the accumulation of biohydrogenation intermediates (e.g., trans-10 18:1, trans-11 18:1, cis-9,trans-11 18:2, trans-10,cis-12 18:2). In addition, Lascano et al. (2016) reported elevated production of trans FA intermediates (e.g., trans-10 18:1, trans-10,cis-12 18:2) associated with milk fat depression when starch degradability was increased from low to high. Results from these 2 studies (Neveu et al., 2014; Lascano et al., 2016) suggest that further research is needed to better understand the potential interactions between oil and cereal grain PS on production and milk FA profile.

We hypothesized that (1) FSO would improve yields of milk and milk components, as well as feed efficiency due to increased energy intake, (2) compared with cracked corn $(\mathbf{C C})$, ground corn (GC) would be more extensively fermented in the rumen, leading to a greater proportion of trans FA intermediates in milk fat and improved milk $\mathrm{N}$ efficiency (i.e., milk $\mathrm{N} / \mathrm{N}$ intake), and (3) FSO would interact with corn grain PS to affect production, milk and plasma FA profile, and nutrient utilization. The objective of the current study was to examine the potential interactions of FSO and corn grain PS on production, milk and plasma FA profile, and nutrient utilization in dairy cows fed diets formulated to contain similar starch concentrations.

\section{MATERIALS AND METHODS}

Care and handling of the animals used in the current study were conducted as outlined in the guidelines of the University of New Hampshire Institutional Animal Care and Use Committee (\#160107). The 96-d-long experiment was conducted at the University of New Hampshire Burley-Demeritt Organic Dairy Research Farm $\left(43^{\circ} 10^{\prime} \mathrm{N}, 70^{\circ} 99^{\prime} \mathrm{W}\right.$; Lee, NH) from February 12 to May 17, 2016.

\section{Animals, Experimental Design, and Treatments}

Twelve multiparous organic-certified Jersey cows averaging (mean $\pm \mathrm{SD}$ ) $455 \pm 41.9 \mathrm{~kg}$ of BW, $152 \pm 34$ DIM, and $22.6 \pm 3.89 \mathrm{~kg} / \mathrm{d}$ of milk and 4 primiparous organic-certified Jersey cows averaging (mean \pm SD) $356 \pm 2.41 \mathrm{~kg}$ of BW, $174 \pm 30 \mathrm{DIM}$, and $17.9 \pm$ $2.46 \mathrm{~kg} / \mathrm{d}$ of milk in the beginning of the experiment were used. Cows were randomly assigned to treatment sequences in a replicated $4 \times 4$ Latin square design with a $2 \times 2$ factorial arrangement of treatments. Distribution of animals to squares was done to balance for differences in DIM and parity, resulting in 3 squares of multiparous cows (square $1=124 \pm 38$ DIM; square $2=149 \pm 1$ DIM; square $3=184 \pm 23$ DIM) and 1 square of primiparous cows (square $4=174 \pm 30$ DIM). Squares were also balanced for potential firstorder carryover effects in subsequent periods as each treatment immediately preceded and followed every other exactly once in each square (Williams, 1949; Kim and Stein, 2009). Each period lasted $24 \mathrm{~d}$ with $18 \mathrm{~d}$ for diet adaptation and $6 \mathrm{~d}$ for data and sample collection. The following dietary treatments were fed (DM basis): (1) $0 \% \mathrm{FSO}+27.1 \% \mathrm{GC},(2) 0 \% \mathrm{FSO}+28.3 \% \mathrm{CC}$, (3) $3 \% \mathrm{FSO}+27.1 \% \mathrm{GC}$, and (4) $3 \% \mathrm{FSO}+28.3 \%$ CC. Inclusion of corn grain sources and soyhulls in the diets varied to obtain treatments with similar concentrations of starch. The 2 types of corn grain used in the present study were purchased from the same mill (Green Mountain Feeds, Bethel, VT), but they were not from the same batch of corn. Treatments were fed as TMR (55:45 forage-to-concentrate ratio) formulated according to the NRC (2001) and balanced to meet or exceed the nutritional requirement of a Jersey cow producing $19 \mathrm{~kg}$ of milk/d, $4.5 \%$ milk fat, and $3.5 \%$ milk true protein. A generic mineral and vitamin lactation dairy premix $(97.6 \% \mathrm{DM})$ fed at $1.98 \%$ of the diet DM consisting of (as-fed basis) Ca (32.7\%), Mn (1.0\%), Zn (1.7\%), Cu $(2,501 \mathrm{mg} / \mathrm{kg}), \mathrm{Co}(282 \mathrm{mg} / \mathrm{kg}), \mathrm{I}(332 \mathrm{mg} /$ 
Table 1. Nutritional composition of feeds used in the experimental diets (\% of DM, unless otherwise noted)

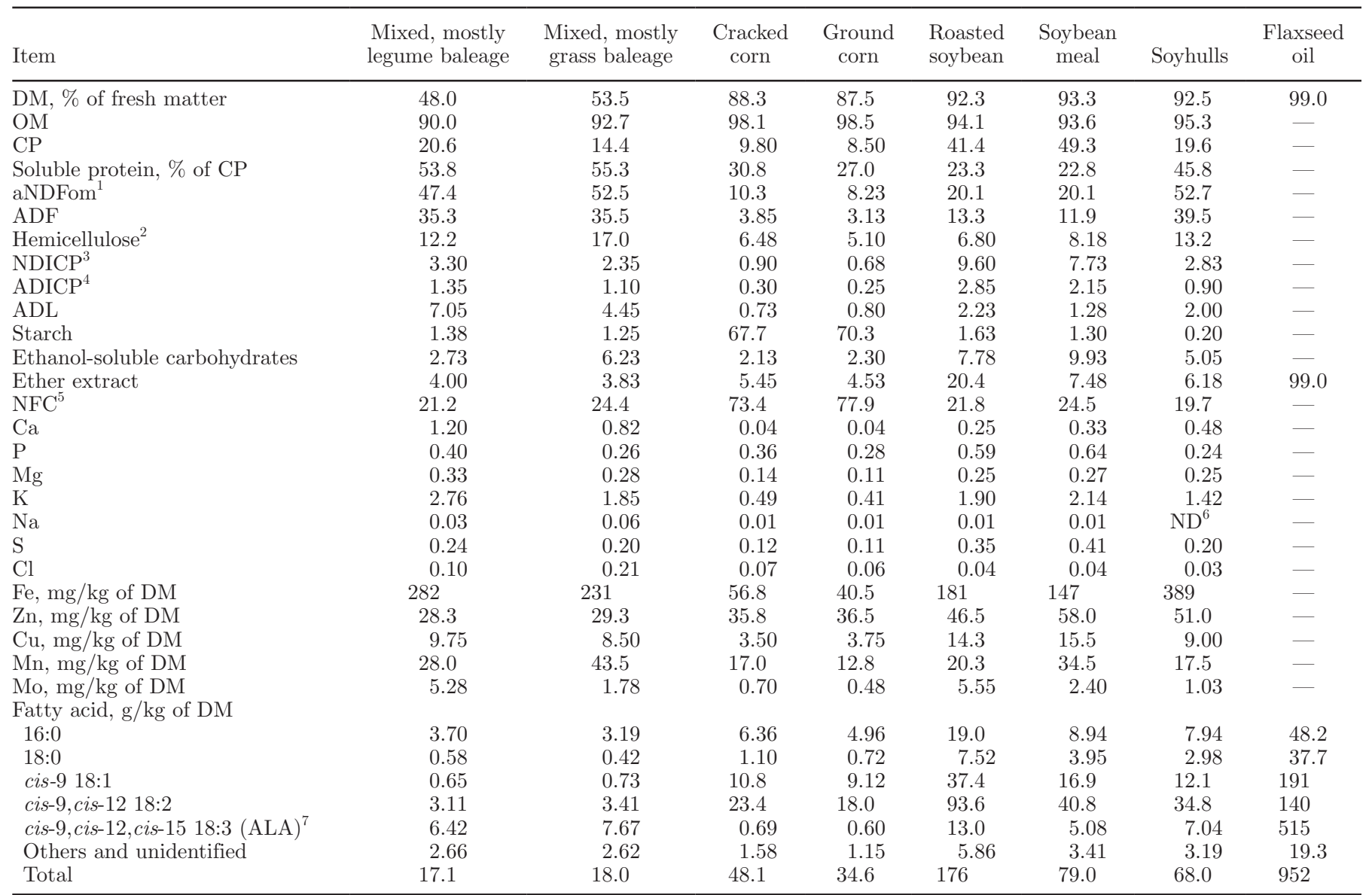

${ }^{1}$ aNDFom $=$ determined with heat-stable amylase and sodium sulfite and expressed free of residual ash.

${ }^{2}$ Hemicellulose $=$ aNDFom - ADF .

${ }^{3} \mathrm{NDICP}=$ neutral detergent insoluble CP.

${ }^{4} \mathrm{ADICP}=$ acid detergent insoluble $\mathrm{CP}$.

${ }^{5} \mathrm{NFC}=100-[\mathrm{CP} \%+($ aNDFom $\%-\mathrm{NDICP} \%)+$ ether extract + ash $]$.

${ }^{6} \mathrm{ND}=$ not detected.

${ }^{7} \mathrm{ALA}=\alpha$-linolenic acid.

$\mathrm{kg})$, Se (106 mg/kg), $\mathrm{Mg}(1.0 \%), \mathrm{Cl}(0.9 \%)$, vitamin A $(2,439,099 \mathrm{IU} / \mathrm{kg})$, vitamin $\mathrm{D}_{3}(665,162 \mathrm{IU} / \mathrm{kg})$, and vitamin $\mathrm{E}(10,182 \mathrm{IU} / \mathrm{kg})$ was used. The nutritional composition of the dietary ingredients is presented in Table 1, and the ingredient and nutritional composition of the experimental diets are presented in Table 2.

Cows were housed in a bedded-pack barn with dried pine shavings as bedding. The bedding area $\left(132 \mathrm{~m}^{2}\right)$ opens to a $478-\mathrm{m}^{2}$ concrete-floor outdoor lot (total pen area $=610 \mathrm{~m}^{2}$ ), allowing cows to walk freely in compliance with the USDA National Organic Program "Livestock living conditions" regulations (section 205.239; https://www.ecfr.gov/cgi-bin/text-idx?SID= 38fb700cb79331adaec0a1e05477134f\&mc $=$ true \&node $=$ se7.3.205_1239\&rgn=div8; accessed September 20, 2017). Treatments were individualized by providing an- imal access to a roof-covered feeding station equipped with electronic recognition Calan doors (American Calan Inc., Northwood, NH) located at the opposite end of the bedding area.

\section{Feeding and Feed Sampling and Analyses}

The forage component of the TMR consisted of first cutting baleage harvested from 2 fields with different botanical composition. Both fields were composed of cool season grass-legume mixes, with field 1 containing predominantly grasses $\{$ e.g., timothy [Phleum pratense L.], orchardgrass [Dactylis glomerata L.], Kentucky bluegrass [Poa pratensis L.], and tall fescue [Schedonorus phoenix (Scop.) Holub]\}, and field 2 predominantly legumes [e.g., red clover (Trifolium pratense L.), 
alfalfa (Medicago sativa L.), and white clover (Trifolium repens L.)]. Forages were harvested as baleage and wrapped with stretch plastic as reported previously (Resende et al., 2015). All bales used in the current study were sampled using a drill (model TE 7-A, Hilti North America, Tulsa, OK) fitted with a 40-cm long metal core sampler. Baleage samples were obtained after 3 to 4 core samplings and then composited to yield individual samples of approximately $150 \mathrm{~g}$. Baleage and concentrate (collected weekly) were dried $\left(55^{\circ} \mathrm{C}, 48 \mathrm{~h}\right)$ in a forced-air oven (VWR Scientific, Bridgeport, NJ) with the resulting DM used to adjust the forage and

Table 2. Ingredient and nutritional composition of the experimental diets

\begin{tabular}{|c|c|c|c|c|}
\hline \multirow[b]{2}{*}{ Item } & \multicolumn{2}{|c|}{$0 \%$ Flaxseed oil } & \multicolumn{2}{|c|}{$3 \%$ Flaxseed oil } \\
\hline & Ground corn & Cracked corn & Ground corn & Cracked corn \\
\hline \multicolumn{5}{|c|}{ Ingredient composition, $\%$ of diet DM } \\
\hline Mixed, mostly legume baleage & 30.0 & 30.0 & 30.0 & 30.0 \\
\hline Mixed, mostly grass baleage & 25.0 & 25.0 & 25.0 & 25.0 \\
\hline Flaxseed oil & - & - & 3.00 & 3.00 \\
\hline Cracked corn, dried & - & 28.3 & - & 28.3 \\
\hline Ground corn, dried & 27.1 & - & 27.1 & - \\
\hline Soybean meal & 7.03 & 7.03 & 7.03 & 7.03 \\
\hline Roasted soybean & 1.98 & 1.98 & 1.98 & 1.98 \\
\hline Soyhulls & 6.91 & 5.71 & 3.91 & 2.71 \\
\hline Minerals and vitamins premix ${ }^{1}$ & 1.98 & 1.98 & 1.98 & 1.98 \\
\hline \multicolumn{5}{|c|}{ Nutritional composition, \% of DM, unless otherwise noted } \\
\hline DM, \% of fresh matter & 51.9 & 51.7 & 51.7 & 50.1 \\
\hline $\mathrm{OM}$ & 91.9 & 91.8 & 92.0 & 92.0 \\
\hline $\mathrm{CP}$ & 17.7 & 18.0 & 17.2 & 17.4 \\
\hline Soluble protein, \% of CP & 42.5 & 43.3 & 41.1 & 41.9 \\
\hline aNDFom $^{2}$ & 35.0 & 35.1 & 33.4 & 33.5 \\
\hline $\mathrm{ADF}$ & 24.1 & 23.9 & 22.9 & 22.7 \\
\hline Hemicellulose $^{3}$ & 10.9 & 11.2 & 10.5 & 10.8 \\
\hline $\mathrm{NDICP}^{4}$ & 2.69 & 2.73 & 2.60 & 2.64 \\
\hline $\mathrm{ADICP}^{5}$ & 1.02 & 1.02 & 0.99 & 1.00 \\
\hline $\mathrm{ADL}$ & 3.72 & 3.68 & 3.66 & 3.62 \\
\hline Starch & 19.9 & 20.0 & 19.9 & 20.0 \\
\hline Ethanol-soluble carbohydrates & 4.21 & 4.10 & 4.06 & 3.95 \\
\hline Ether extract & 4.73 & 4.98 & 7.52 & 7.76 \\
\hline $\mathrm{NFC}^{6}$ & 37.1 & 36.5 & 36.5 & 35.9 \\
\hline $\mathrm{Ca}$ & 0.65 & 0.64 & 0.63 & 0.63 \\
\hline $\mathrm{P}$ & 0.33 & 0.36 & 0.33 & 0.35 \\
\hline \multicolumn{5}{|l|}{ Fatty acids, $\mathrm{g} / \mathrm{kg}$ of DM } \\
\hline $16: 0$ & 4.83 & 5.15 & 6.03 & 6.36 \\
\hline $18: 0$ & 1.12 & 1.18 & 2.16 & 2.22 \\
\hline cis-9 18:1 & 5.64 & 6.07 & 11.0 & 11.5 \\
\hline cis-9,cis-12 18:2 & 13.9 & 15.1 & 17.1 & 18.2 \\
\hline cis-9,cis-12,cis-15 18:3 (ALA) ${ }^{7}$ & 5.13 & 5.04 & 20.4 & 20.3 \\
\hline Others and unidentified & 2.35 & 2.44 & 2.83 & 2.92 \\
\hline Total & 36.1 & 33.0 & 59.5 & 62.6 \\
\hline \multicolumn{5}{|l|}{ NRC (2001) estimates ${ }^{8}$} \\
\hline RDP, \% of diet DM & 11.3 & 11.4 & 11.0 & 11.1 \\
\hline RUP, $\%$ of diet DM & 6.40 & 6.50 & 6.10 & 6.20 \\
\hline MP balance, $\mathrm{g} / \mathrm{d}$ & 238 & 276 & 217 & 226 \\
\hline Digestible Lys, \% of MP & 6.45 & 6.37 & 6.56 & 6.48 \\
\hline Digestible Met, $\%$ of MP & 1.81 & 1.81 & 1.84 & 1.84 \\
\hline MP-Lys:MP-Met ratio & 3.56 & 3.52 & 3.57 & 3.52 \\
\hline $\mathrm{NE}_{\mathrm{L}}, \mathrm{Mcal} / \mathrm{kg}$ & 1.64 & 1.64 & 1.75 & 1.75 \\
\hline
\end{tabular}

${ }^{1}$ The mineral and vitamin premix was composed (as-fed basis) of Ca (32.7\%), Mn (1\%), Zn (1.7\%), Cu (2,501 mg/kg), Co (282 mg/kg), I (332 $\mathrm{mg} / \mathrm{kg}), \mathrm{Se}(106 \mathrm{mg} / \mathrm{kg}), \mathrm{Mg}(1 \%), \mathrm{Cl}(0.9 \%)$, vitamin A (2,439,099 IU $/ \mathrm{kg})$, vitamin $\mathrm{D}_{3}(665,162 \mathrm{IU} / \mathrm{kg})$, and vitamin E (10,182 IU $\left./ \mathrm{kg}\right)$.

${ }^{2}$ aNDFom $=$ determined with heat-stable amylase and sodium sulfite and expressed free of residual ash.

${ }^{3}$ Hemicellulose $=$ aNDFom - ADF .

${ }^{4} \mathrm{NDICP}=$ neutral detergent insoluble CP.

${ }^{5} \mathrm{ADICP}=$ acid detergent insoluble $\mathrm{CP}$.

${ }^{6} \mathrm{NFC}=100-[\mathrm{CP} \%+($ aNDFom $\%-\mathrm{NDICP} \%)+$ ether extract + ash $]$.

${ }^{7} \mathrm{ALA}=\alpha$-linolenic acid.

${ }^{8}$ Determined using the NRC (2001) including actual feed nutritional composition and animal variables (i.e., DMI, milk yield and composition, DIM, and BW). 
concentrate proportions of the as-fed TMR. Bales were chopped for approximately 20 min using a vertical mixer (Valmetal V-Mix 400, Saint-Germain-de-Grantham, QC, Canada) every 2 d. Dietary ingredients, including water, were loaded in an A100 self-propelled mixer (Jaylor Fabricating Inc., East Garafraxa, ON, Canada) and mixed for at least 10 min to obtain TMR with a target DM of $50 \%$. Diets were offered ad libitum twice daily at 0630 and $1600 \mathrm{~h}$, with about $40 \%$ of the daily TMR allocation fed in the morning and the remaining $60 \%$ in the afternoon to account for uneven intervals between feeding times (i.e., $9.5 \mathrm{~h}$ between 0630 and $1600 \mathrm{~h}$ and $14.5 \mathrm{~h}$ between 1600 and 0630 $\mathrm{h})$. The amount of TMR offered to the animals was recorded using the A100 self-propelled mixer (Jaylor Fabricating Inc.) and adjusted daily to yield refusals of approximately 5 to $10 \%$ of the as fed intake. Refusals were collected daily before the afternoon feeding and weighed as done for the TMR. Animals had free access to clean water throughout the duration of the study. Body weights were recorded (Northeast Scale Co. Inc., Hooksett, NH) immediately after the afternoon milking for 3 consecutive days before $\mathrm{d} 1$ of the experiment and during the last $3 \mathrm{~d}$ of each period.

Samples of concentrate used for nutritional analyses were collected on d 20 of each period. Baleages, TMR, and refusals were collected daily from d 18 to 24 of each period and individual composites over the 7-d period were made. Samples of TMR were collected and composited by diet, whereas individual cow refusal samples were collected and composited by treatment. All TMR, feeds, and refusals were dried in a forced-air oven $\left(55^{\circ} \mathrm{C}, 48 \mathrm{~h}\right)$ and ground through a $1-\mathrm{mm}$ screen (Willey mill, Arthur H. Thomas Co., Philadelphia, PA). Baleages and concentrates were shipped to Dairy One Cooperative Inc. (Ithaca, NY) and analyzed for DM (method 930.15; AOAC International, 2016), CP (total $\mathrm{N} \times 6.25$; method 990.03; AOAC International, 2016), amylase and sodium sulfite treated NDF exclusive of ash [aNDFom; Ankom Technology method 6, Fairport, NY; solutions as in Van Soest et al. (1991)], ADF [Ankom Technology method 5; solutions as in method 973.18 (AOAC International, 2016)], neutral detergent insoluble CP (Leco TruMac N Macro Determinator on a NDF residue), acid detergent insoluble CP (Leco TruMac N Macro Determinator on ADF residue), ADL (Ankom Technology method 9 in a Daisy II Incubator), ether extract [extraction by a Soxtec HT6 System (Foss North America, Eden Prairie, MN) using anhydrous diethyl ether; method 2003.05; AOAC International, 2016], ethanol soluble carbohydrates (Hall et al., 1999), ash (method 942.05; AOAC International, 2016), Ca, $\mathrm{P}, \mathrm{Mg}, \mathrm{K}, \mathrm{Na}, \mathrm{Fe}, \mathrm{Zn}, \mathrm{Cu}, \mathrm{Mn}, \mathrm{Mo}$, and S [inductively coupled plasma mass spectrophotometry using an iCAP
6300 Inductively Coupled Plasma Radial Spectrometer (Thermo Fisher Scientific Inc., Waltham, MA)] after microwave digestion (CEM application note for acid digestion; CEM, Mathews, $\mathrm{NC}$ ), and $\mathrm{Cl}$ ion (Brinkmann Metrohm 716 Titrino Titration Unit with a silver electrode, Metrohm application bulletin no. 130; Metrohm Ltd., Herisau, Switzerland). Baleages, concentrates, and FSO were shipped to the Pennsylvania State University (Kevin Harvatine Laboratory, University Park) for determination of FA using GLC after direct methylation (Sukhija and Palmquist, 1988). Starch was measured using an YSI 2700 SELECT Biochemistry Analyzer (Application Note Number 319; YSI Inc. Life Sciences, Yellow Springs, OH). In brief, samples were pre-extracted for sugar by incubation in water bath at $40^{\circ} \mathrm{C}$ followed by filtration using Whatman 41 filter paper (Cole-Parmer, Vernon Hills, IL). Next, residues were thermally solubilized using an autoclave and then incubated with glucoamylase to hydrolyze starch and produce dextrose. Dextrose was immediately oxidized to hydrogen peroxide and D-glucono-4-lactone, with hydrogen peroxide concentration being directly proportional to dextrose concentration. Starch was finally determined by multiplying dextrose by 0.9 .

Approximately $0.5 \mathrm{~g}$ of feed and fecal samples were weighed into Ankom F57 bags (Ankom Technology), placed in 1 larger laundry bag, and inserted in the rumen of 1 ruminally cannulated lactating Jersey cow for $12 \mathrm{~d}$. After removal from the rumen, bags were rinsed with tap water and analyzed for ADF as described above. Feeds and fecal indigestible ADF (iADF) was used as an intrinsic marker to estimate fecal output of DM and apparent total-tract digestibility of nutrients (Cochran et al., 1986; Huhtanen et al., 1994). Corn grain samples were shipped (Dairyland Inc., Arcadia, WI) for determination of PS according to Baker and Herrman (2002) using a Ro-Tap Sieve Shaker (model RX-29; W.S. Tyler, Mentor, OH) equipped with 14 sieves of various sized apertures [US sieve no. $4(4,750$ $\mu \mathrm{m}), 6(3,350 \mu \mathrm{m}), 8(2,360 \mu \mathrm{m}), 12(1,700 \mu \mathrm{m}), 16$ $(1,180 \mu \mathrm{m}), 20(850 \mu \mathrm{m}), 30(600 \mu \mathrm{m}), 40(425 \mu \mathrm{m}), 50$ $(300 \mu \mathrm{m}), 70(212 \mu \mathrm{m}), 100(150 \mu \mathrm{m}), 140(106 \mu \mathrm{m})$, $200(75 \mu \mathrm{m})$, and $270(53 \mu \mathrm{m})$ ] plus a bottom pan. Calculations of corn grain PS distribution as presented in Table 3 were done following Baker and Herrman (2002). Refusals were analyzed for DM, ash, aNDFom, $\mathrm{ADF}$, starch, and total $\mathrm{N}$ based on the methods reported above.

\section{Milk Sampling and Analyses}

Cows were milked twice daily at 0530 and $1530 \mathrm{~h}$ in a 4-stall step-up parlor equipped with headlocks (Agromatic, Fond du Lac, WI), automatic take-offs, and 
milk meters (Westfalia Surge, GEA Farm Technologies Inc., Naperville, IL). Milk weights were recorded daily throughout the duration of the experiment (DairyPlan C21 Version 5.2, GEA Farm Technologies Inc.). Milk samples were collected for 4 consecutive milkings (d 20 to 22 of each period), preserved using 2-bromonitropropan-1,3 diol (Broad Spectrum Microtabs II, Advanced Instruments Inc., Norwood, MA), and pooled by cow according to afternoon and morning milk weights. Composited milk samples were stored at $4^{\circ} \mathrm{C}$ until shipped to Dairy One Cooperative Inc. for determination of fat, true protein, lactose, MUN, SNF, and TS by Fourier transform infrared spectroscopy using a MilkoScan FT+ (Foss Inc., Hillerød, Denmark) and SCC by flow cytometry in a Fossomatic FC (Foss Inc.). Milk samples without preservative were collected for 2 consecutive milkings (d 20 to 21 ), pooled using the same procedure described above, and stored at $-80^{\circ} \mathrm{C}$ until shipped to the Pennsylvania State University (Kevin Harvatine Laboratory) for FA analysis using GLC according to Rico and Harvatine (2013).

\section{Blood Sampling and Analyses}

Blood samples were taken once daily on d 24 of each period at approximately $5 \mathrm{~h}$ after the morning feeding by venipuncture of the coccygeal vein or artery into 10$\mathrm{mL}$ lithium heparin-containing vacutainer tubes (Becton Dickinson, Franklin Lakes, NJ). Tubes were placed immediately on ice and centrifuged within $1 \mathrm{~h}$ after collection using an Eppendorf centrifuge model 5810 (Hamburg, Germany) set at $1,500 \times g$ for 20 min at $4^{\circ} \mathrm{C}$. The first set of plasma aliquots was stored at $-80^{\circ} \mathrm{C}$ until shipped to the Pennsylvania State University for FA analysis using GLC (Kevin Harvatine Laboratory), whereas the second set of plasma aliquots was stored at $-20^{\circ} \mathrm{C}$ for later analysis of plasma urea $\mathrm{N}$ (PUN). Concentration of PUN was determined colorimetrically using a UV/visible spectrophotometer (Beckman Coul- ter Inc., Brea, CA) set at a wavelength of $540 \mathrm{~nm}$ using the diacetyl-monoxime method (Rosenthal, 1955).

\section{Urinary and Fecal Sampling and Analyses}

Spot samples of urine were collected by stimulation of the pudendal nerve, massaging the area below the vulva on d 20 to 22 of each sampling period at 0800,1200 , and $1700 \mathrm{~h}$ to account for potential diurnal variation in urinary excretion of creatinine and purine derivatives (PD). After collection, urinary samples were immediately transported to the laboratory. Individual $2.8-\mathrm{mL}$ subsamples were pooled over $3 \mathrm{~d}$, yielding a total of $8.4 \mathrm{~mL}$ of urine, which was placed in $50-\mathrm{mL}$ centrifuge tubes containing $33.6 \mathrm{~mL}$ of $0.072 \mathrm{~N} \mathrm{H}_{2} \mathrm{SO}_{4}$ and stored at $-20^{\circ} \mathrm{C}$ for later analyses of creatinine, allantoin, uric acid, and total N. After thawing at room temperature, urinary samples were analyzed colorimetrically for concentrations of creatinine (assay kit no. 500701, Cayman Chemical Co., Ann Arbor, MI) using a chromate microplate reader set at a wavelength of $492 \mathrm{~nm}$ (Awareness Technology Inc., Palm City, FL), allantoin (Chen et al., 1992), uric acid (assay kit no. 1045-225; Stanbio Laboratory, Boerne, TX), and total N (micro-Kjeldahl analysis, AOAC, 1990; Dairy One Cooperative Inc.). Allantoin and uric acid were read at wavelengths of 522 and $520 \mathrm{~nm}$, respectively, on a UV/visible spectrophotometer (Beckman Coulter Inc.). Daily urinary volume was estimated from the concentration of creatinine in the urine assuming a constant creatinine excretion rate of $0.212 \mathrm{mmol} / \mathrm{kg}$ of BW (Chizzotti et al., 2008). Urinary excretion of total $\mathrm{N}$, allantoin, uric acid, and total PD (allantoin + uric acid) was calculated by multiplying the concentration of each of these metabolites by the urinary volume.

Fecal grab samples were collected concurrently with urine on d 20 to 22 of each period, dried in a forced-air oven $\left(55^{\circ} \mathrm{C}, 96 \mathrm{~h}\right)$, ground through a $1-\mathrm{mm}$ screen (Willey mill), and composited over the $3 \mathrm{~d}$ by mixing equal

Table 3. Corn grain particle size distribution $(\text { mean } \pm \mathrm{SD})^{1}$

\begin{tabular}{|c|c|c|}
\hline \multirow[b]{2}{*}{ Item } & \multicolumn{2}{|c|}{ Corn grain } \\
\hline & Ground & Cracked \\
\hline $\begin{array}{l}\text { Mean particle size, } \mu \mathrm{m} \\
\text { Geometric } \mathrm{SD}, \mu \mathrm{m}^{2} \\
\text { SD distribution, } \mu \mathrm{m} \\
\text { Surface area, } \mathrm{cm}^{2} / \mathrm{g} \\
\text { Particles } / \mathrm{g} \text { of sample, no. }\end{array}$ & $\begin{aligned} 580 & \pm 108 \\
2.77 & \pm 0.24 \\
201( \pm 38.3) & \text { to } 1,676( \pm 313) \\
141 & \pm 23.5 \\
737,562 & \pm 397,044\end{aligned}$ & $\begin{aligned} 2,047 & \pm 249 \\
2.09 & \pm 0.28 \\
1,006( \pm 244) & \text { to } 4,217( \pm 138) \\
29.9 & \pm 6.95 \\
1,877 & \pm 2,313\end{aligned}$ \\
\hline
\end{tabular}


amounts of dried materials. Composites were shipped to a commercial laboratory (Dairy One Cooperative Inc.) for analyses of DM, ash, aNFDom, ADF, total N, and starch as reported previously.

\section{Statistical Analyses}

Data were analyzed as a replicated $4 \times 4$ Latin square design with a $2 \times 2$ factorial arrangement of treatments using the MIXED procedure of SAS (SAS version 9.4, SAS Institute Inc., Cary, NC). The following model was fitted to all animal-related variables:

$$
\begin{aligned}
\mathrm{Y}_{\mathrm{ijklm}}=\mu & +\mathrm{P}_{\mathrm{i}}+\mathrm{S}_{\mathrm{j}}+\mathrm{C}_{\mathrm{k}(\mathrm{j})}+\mathrm{FSO}_{\mathrm{l}}+\mathrm{PS}_{\mathrm{m}} \\
& +\mathrm{FSO} \times \mathrm{PS}_{\mathrm{lm}}+\varepsilon_{\mathrm{ijklm}},
\end{aligned}
$$

where $Y_{i j k l m}$ is the dependent variable, $\mu$ is the overall mean, $\mathrm{P}_{\mathrm{i}}$ is the fixed effect of the ith period, $\mathrm{S}_{\mathrm{j}}$ is the fixed effect of the jth square, $\mathrm{C}_{\mathrm{k}(\mathrm{j})}$ is the random effect of kth cow nested in the jth square, $\mathrm{FSO}_{1}$ is the fixed effect of the lth dietary level of FSO (0 vs. $3 \%$ ), $\mathrm{PS}_{\mathrm{m}}$ is the fixed effect of mth corn grain PS (GC vs. CC), $\mathrm{FSO} \times \mathrm{PS}_{\mathrm{lm}}$ is the interaction between lth dietary level of FSO and mth corn grain PS, and $\varepsilon_{\mathrm{ijklm}}$ is the error term. Orthogonal contrasts were used to test the effects of dietary level of FSO, corn grain PS, and the interaction between FSO level and corn grain PS. All reported values are least squares means \pm standard error of the mean. Significance was declared at $P \leq 0.05$ and trends at $0.05<P \leq 0.10$.

\section{RESULTS AND DISCUSSION}

\section{Feeds and Diets Nutritional Composition}

The starch concentration of GC averaged $70.3 \%$ and was 2.6 percentage units numerically greater than that of CC (Table 1). As expected, the concentrations of ALA and cis-9,cis-12 18:2 were numerically greatest in FSO (Table 1). The nutritional composition of soyhulls fed in the present study was not typical. Specifically, the concentrations of $\mathrm{CP}$ and ether extract were 7.8 and 3.5 percentage units greater, and those of aNDFom and ADF were 12.9 and 8.2 percentage units lower, respectively, than mean values reported in the metaanalysis of Ipharraguerre and Clark (2003). However, with the exception of ether extract, our soyhulls values were within or very close to the range of $\mathrm{CP}$, NDF, ADF, hemicellulose, ADL, and starch published by Ipharraguerre and Clark (2003). These discrepancies compared with data from Ipharraguerre and Clark (2003) suggest a possible contamination. The dietary concentration of starch was similar across diets and av- eraged $20 \%$, whereas the inclusion of FSO increased the dietary concentrations of ether extract and total FA by 57 and $43 \%$, respectively (Table 2 ). The concentrations of $\mathrm{CP}$, aNDFom, and $\mathrm{ADF}$ were slightly greater in $0 \%$ versus $3 \%$ FSO diets due to soyhulls making up the difference in ingredient composition between treatments. The dietary concentration of individual FA in the diets followed the FA profile of the dietary ingredients. For instance, the concentration of ALA numerically increased by $300 \%$ in diets supplemented with $3 \%$ FSO (Table 2).

The mean PS of GC averaged $580 \mu \mathrm{m}$ and was 3.5fold numerically lower than the mean PS of CC, which averaged 2,047 $\mu \mathrm{m}$ (Table 3). This numerical difference in mean PS resulted in less surface area for GC (29.9 $\left.\mathrm{cm}^{2} / \mathrm{g}\right)$ than $\mathrm{CC}\left(141.1 \mathrm{~cm}^{2} / \mathrm{g}\right)$ and more particles per gram of sample $(737,562$ vs. 1,877 ; Table 3$)$. The mean PS observed for GC and CC fed in the present study is within the range (500 to $4,000 \mu \mathrm{m})$ reported for dry $\mathrm{GC}, \mathrm{CC}$, and rolled corn in a meta-analysis conducted by Ferraretto et al. (2013).

\section{Flaxseed Oil × Corn Grain Particle Size Interaction}

An interaction $(P=0.05)$ between FSO supplementation and corn grain PS was observed for milk lactose as the difference in concentration between GC and CC cows was larger when feeding $0 \% \mathrm{FSO}(-0.05$ percentage units) than $3 \%$ FSO (+0.01 percentage units; Table 4). However, these differences were negligible and likely not biologically meaningful.

Significant FSO $\times$ PS interactions $(P \leq 0.04)$ were also observed for the milk proportions of the branchedchain FA iso 16:0 and iso 17:0 (Table 5), and for ALA, cis-5, cis-8,cis-11,cis-14,cis-17 20:5, and En-3 FA (Table 6). Except for iso 16:0, the proportion differences between GC and CC were larger when feeding 3\% than $0 \%$ FSO. The FSO $\times$ PS interaction for iso 16:0 proportion in milk $(P<0.01$; Table 5$)$ was consistent with that detected for iso 16:0 in plasma $(P=0.03$; Table 7 ), indicating that this branched-chain FA of microbial origin was greatest when cows were fed 0\% FSO + GC. Specific to ALA, its proportion in milk was greatest when feeding GC $+3 \%$ FSO (Table 6). Lascano et al. (2016) reported that the outflow of ALA either tended to increase when the starch degradability of corn grain varied from low to high or increased significantly when feeding soybean oil to fermentors during continuous culture. They also observed a reduction in ALA biohydrogenation with the increase in corn grain starch degradability (Lascano et al., 2016). Therefore, the greatest proportion of milk ALA in cows fed GC + $3 \%$ FSO suggests decreased ruminal biohydrogenation resulting in increased escape of ALA. An FSO $\times$ PS 
Table 4. Effect of flaxseed oil (FSO) supplementation (0 vs. 3\% FSO) and corn grain [ground corn (GC) vs. cracked corn (CC)] particle size (PS) on DMI, milk yield and composition, and plasma concentration of urea N (PUN) in Jersey cows

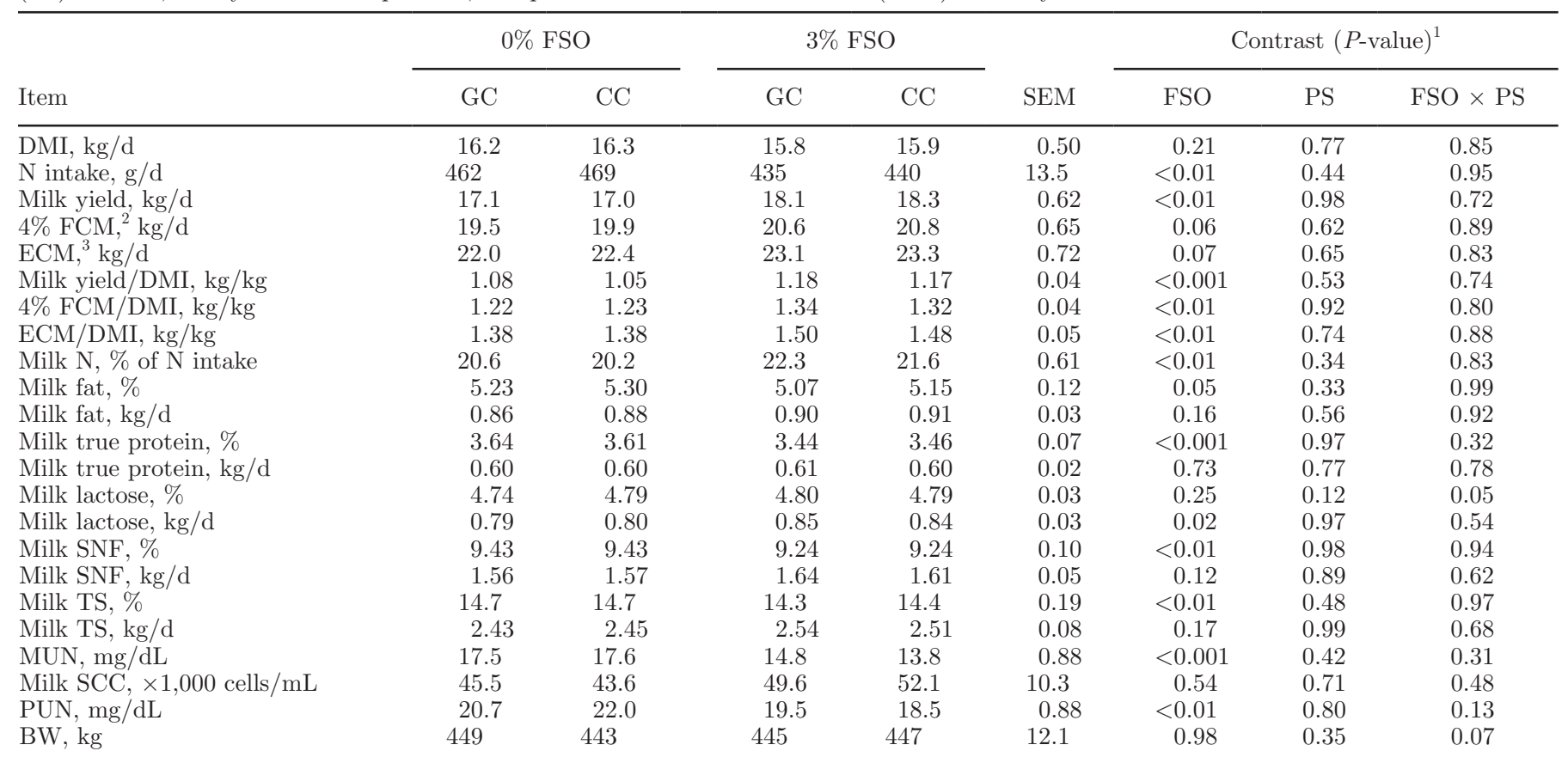

${ }^{1}$ Probability of FSO level main effect ( 0 vs. $3 \%$ FSO); probability of corn grain PS main effect (GC vs. CC); and probability of FSO level $\times$ corn grain PS interaction. Significance was declared at $P \leq 0.05$ and trends at $0.05<P \leq 0.10$.

${ }^{2} 4 \% \mathrm{FCM}=[0.40 \times$ milk yield $(\mathrm{kg} / \mathrm{d})]+[15 \times$ milk fat yield $(\mathrm{kg} / \mathrm{d})]$ (Gaines and Davidson, 1923).

${ }^{3} \operatorname{ECM}(\mathrm{kg} / \mathrm{d})=[0.0752 \times$ milk yield $(\mathrm{kg} / \mathrm{d})]+[12.3 \times$ fat yield $(\mathrm{kg} / \mathrm{d})]+[6.56 \times$ SNF yield $(\mathrm{kg} / \mathrm{d})]($ Tyrrell and Reid, 1965)

interaction was detected for the proportion of ALA in plasma $(P=0.02$; Table 7$)$, further reinforcing that milk ALA responses may have been associated with decreased ruminal biohydrogenation of ALA with feeding $\mathrm{GC}+3 \%$ FSO. The FSO $\times$ PS interactions observed for $\Sigma$ n-3 FA in milk $(P<0.01$; Table 6$)$ and plasma $(P$ $=0.03$; Table 7 ) are explained by the greatest contribution of ALA to total n-3 FA. An FSO $\times$ PS interaction $(P<0.01$; Table 7$)$ was found for the proportion of cis-9 14:1 in plasma, but not in milk (Table 6). This inconsistency may be associated with the activity of stearoyl-CoA desaturase (i.e., $\Delta^{9}$-desaturase) in the mammary gland, which can desaturase 14:0 to produce cis-9 14:1 (Griinari et al., 2000).

\section{Main Effect of Flaxseed Oil}

Production and Milk Composition. Feeding 3\% FSO to lactating dairy cows had no effect on DMI (Table 4). Intake of DM was also not affected in studies where lactating dairy cows were fed FSO varying from 2 to $4 \%$ (Loor et al., 2005; Bu et al., 2007; Benchaar et al., 2012, 2014; Pi et al., 2016). In contrast, DMI decreased by $35 \%$ in lactating dairy cows fed $5.8 \%$ FSO compared with the control treatment (Chilliard et al., 2009). Milk yield increased $(P<0.01)$ by $7 \%$ in cows fed $3 \%$ versus $0 \%$ FSO (Table 4), which is possibly explained by increased intake of dietary energy. In fact, $\mathrm{NE}_{\mathrm{L}}$ of diets supplemented with $3 \% \mathrm{FSO}$ was numerically greater than that of diets without FSO (1.75 vs. $1.64 \mathrm{Mcal} / \mathrm{kg}$ of DM, respectively; Table 2). Our results are consistent with those from previous studies where milk yield increased by an average of $10 \%$ in cows fed FSO ranging from 2 to $4 \%$ of the diet DM (Bu et al., 2007; Benchaar et al., 2012, 2014; Pi et al., 2016). However, results of FSO supplementation on milk yield have been inconsistent. For instance, whereas Loor et al. (2005) and Benchaar et al. (2015) observed no effect on milk yield when cows were supplemented with 3 or 4\% FSO, respectively, Chilliard et al. (2009) reported a $22 \%$ decrease in milk yield with $5.8 \%$ FSO supplementation. These results collectively suggest that the level of inclusion of FSO in dairy diets should not exceed $4 \%$ of the diet DM at risk of depressed DMI and milk yield. Yields of $4 \% \mathrm{FCM}(P=0.06)$ and $\mathrm{ECM}(P=0.10)$ tended to increase in cows fed $3 \%$ versus $0 \%$ FSO diets (Table 4). Feed efficiency expressed as milk yield/DMI $(P<0.001), 4 \%$ FCM/DMI $(P<0.01)$, and ECM/ DMI $(P=0.01)$ increased as a result of improved milk yield and similar DMI in 3\% versus $0 \%$ FSO cows; milk $\mathrm{N}$ efficiency also increased $(P<0.01)$ in cows fed $3 \%$ FSO (Table 4). 
The concentration of milk fat decreased $(P=0.05)$ in cows supplemented with 3\% FSO compared with those fed no FSO (Table 4). Milk (Table 6) and plasma (Table 7) proportions of trans-10 18:1 significantly increased with feeding $3 \%$ FSO. It is well established the involvement of trans-10, cis-12 18:2 (not detected in the current study; Baumgard et al., 2002) and trans-10 18:1 (Shingfield et al., 2009) in the etiology of milk fat depression in dairy cows. However, the trans-11/trans- 10 ratio in milk was greater in $3 \%$ versus $0 \%$ FSO cows $(P$ $<0.01$; Table 6) and did not differ in plasma (Table 7). Thus, the potential effect of trans-10 18:1 on milk fat depression should be interpreted cautiously. Depressed ruminal acetate when feeding 3\% FSO may have been also involved with the observed reduction in milk fat concentration. The apparent total-tract digestibility of
aNDFom $(P<0.01)$ and $\operatorname{ADF}(P=0.01)$ decreased in $3 \%$ FSO cows (Table 8), suggesting depression of cellulolytic microorganisms as fiber is primarily digested in the rumen. Resende et al. (2015) observed a linear reduction in the ruminal molar proportion of acetate in lactating Jersey cows fed baleage-based diets supplemented with incremental amounts of ground flaxseed $(0,5,10$, or $15 \%$ of the diet DM). Furthermore, increased milk volume in cows fed 3\% FSO may have also been involved in decreased milk fat concentration due to a dilution effect. Milk fat yield was not affected by FSO supplementation because the reduction in milk fat concentration was offset by the increase in milk yield (Table 4).

The concentration of milk true protein decreased $(P$ $<0.001$ ), but milk true protein yield did not differ sig-

Table 5. Effect of flaxseed oil (FSO) supplementation (0 vs. 3\% FSO) and corn grain [ground corn (GC) vs. cracked corn (CC)] particle size (PS) on milk proportion of SFA in Jersey cows

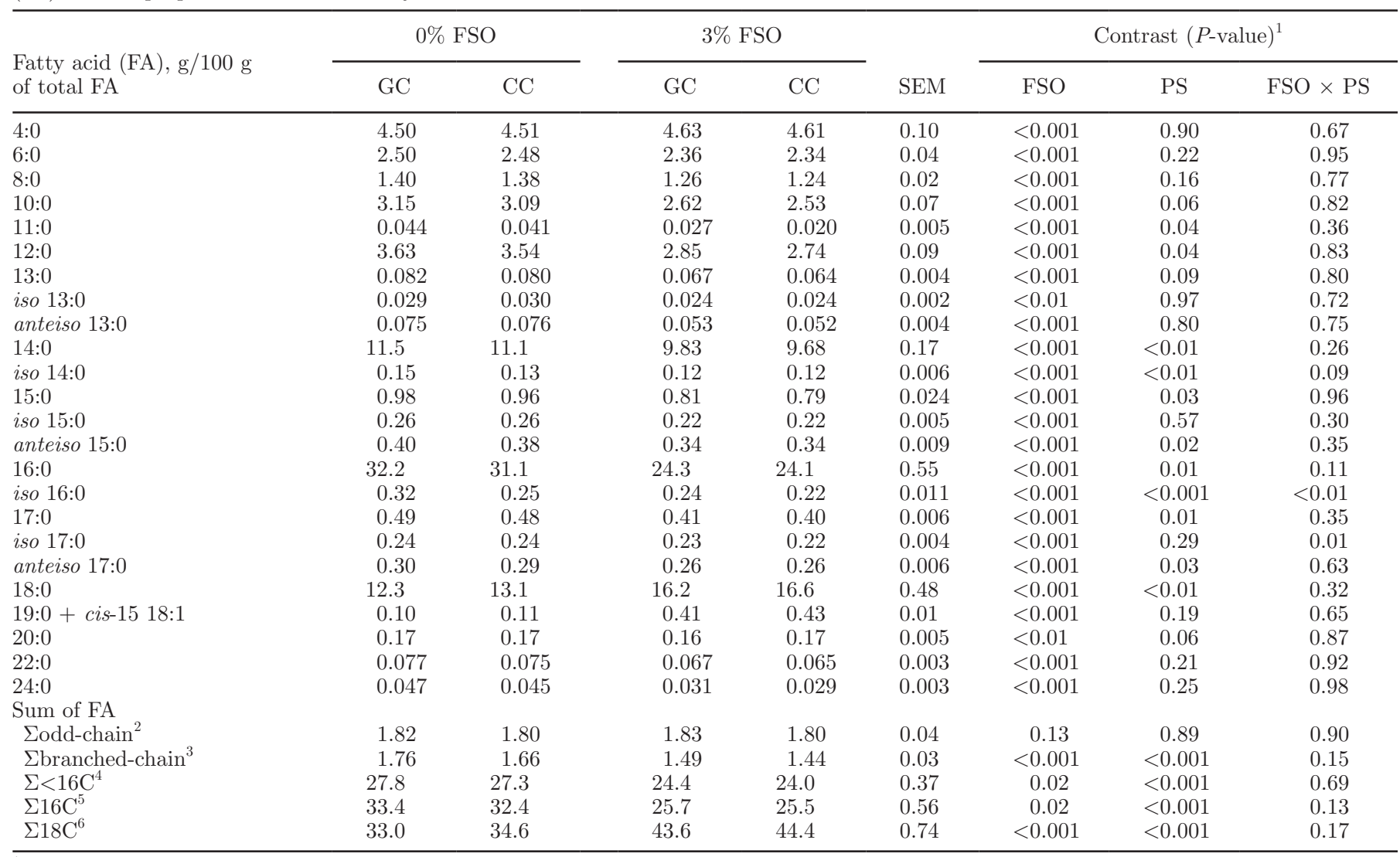

${ }^{1}$ Probability of FSO level main effect ( 0 vs. $3 \%$ FSO); probability of corn grain PS main effect (GC vs. CC); and probability of FSO level $\times$ corn grain PS interaction. Significance was declared at $P \leq 0.05$ and trends at $0.05<P \leq 0.10$

${ }^{2}$ Lodd-chain FA $=11: 0+13: 0+15: 0+17: 0+$ cis-9 17:1 (see Table 6$)$.

${ }^{3}$ Sbranched-chain $\mathrm{FA}=$ iso 13:0 + anteiso 13:0 + iso 14:0 + iso 15:0 + anteiso 15:0 + iso 16:0 + iso 17:0 + anteiso 17:0.

${ }^{4} \Sigma<16 \mathrm{C}$ FA (originated from de novo synthesis in the mammary gland) $=4: 0+6: 0+8: 0+10: 0+12: 0+14: 0+10: 1$ (see Table 6 ) + cis-9 14:1 (see Table 6).

${ }^{5} \Sigma 16 \mathrm{C}$ FA (originated from de novo synthesis in the mammary gland and extraction from plasma) $=16: 0+$ cis-9 16:1 (see Table 6) + trans-16:1 UFA (see Table 6).

${ }^{6} \Sigma 18 \mathrm{C}$ FA (originated from plasma extraction) $=18: 0+$ all 18C UFA (see Table 6 ). 
nificantly in cows supplemented with $3 \%$ FSO (Table 4 ), indicating no change in milk protein synthesis. Therefore, this drop in milk true protein concentration was likely caused by an increase in milk volume with feeding 3\% FSO. Literature reports have been inconsistent relative to the effects of FSO supplementation on milk true protein concentration and yield independent of the amount of FSO fed. For instance, supplementation of FSO ranging from 2 to 4\% (Loor et al., 2005; Bu et al., 2007; Benchaar et al., 2012; Pi et al., 2016) did not affect the concentration and yield of milk protein in dairy cows. In contrast, feeding $3 \%$ FSO tended to decrease (Benchaar et al., 2014), whereas 4\% FSO
(Benchaar et al., 2015) decreased the concentration and yield of milk protein in dairy cows. At a greater supplementation rate (i.e., $5.8 \%$ FSO), milk protein content was not changed, but yield decreased by $20 \%$ (Chilliard et al., 2009). It appears that the ingredient composition of the basal diet, particularly the forage source used, may interact with FSO to modulate ruminal and postruminal metabolic processes associated with milk protein synthesis in the mammary gland, thus warranting further research.

Milk lactose yield followed milk yield and increased $(P=0.02)$ in cows supplemented with $3 \%$ FSO (Table $4)$. Concentrations of milk SNF $(P<0.01)$ and TS $(P$

Table 6. Effect of flaxseed oil (FSO) supplementation (0 vs. 3\% FSO) and corn grain [ground corn (GC) vs. cracked corn (CC)] particle size (PS) on milk proportion of UFA in Jersey cows

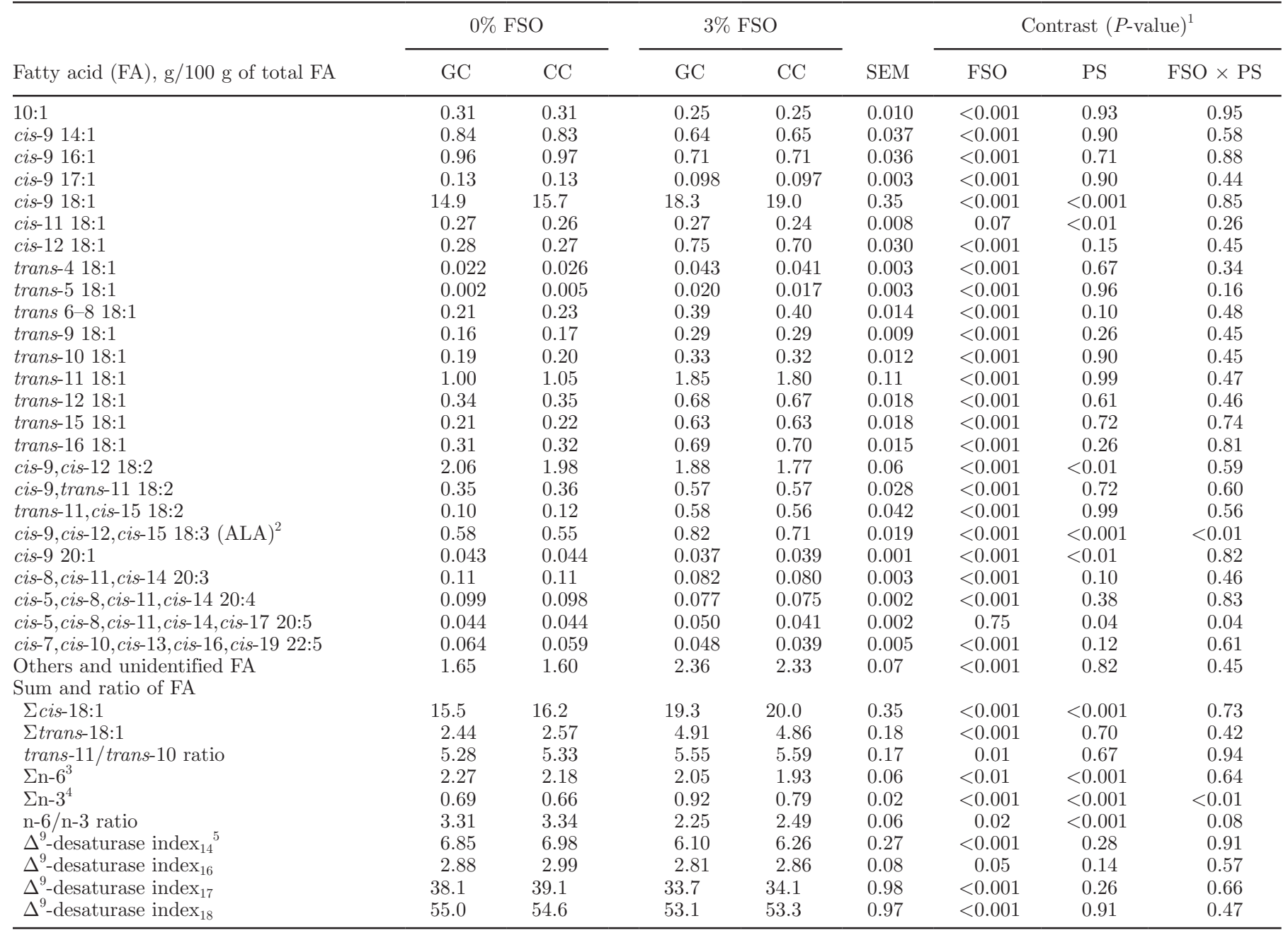

${ }^{1}$ Probability of FSO level main effect (0 vs. $3 \%$ FSO); probability of corn grain PS main effect (GC vs. CC); and probability of FSO level $\times$ corn grain PS interaction. Significance was declared at $P \leq 0.05$ and trends at $0.05<P \leq 0.10$.

${ }^{2} \mathrm{ALA}=\alpha$-linolenic acid.

${ }^{3} \mathrm{Nn}-6 \mathrm{FA}=$ cis-9,cis-12 18:2+cis-8,cis-11,cis-14 20:3 + cis-5,cis-8, cis-11,cis-14 20:4.

${ }^{4} \mathrm{n}$-3 FA $=$ cis-9,cis-12,cis-15 18:3 + cis-5,cis-8,cis-11,cis-14,cis-17 20:5 + cis-7,cis-10,cis-13,cis-16, cis-19 22:5.

${ }^{5} \Delta^{9}$-desaturase index ${ }_{14}=$ cis-9 14:1 $\div\left(14: 0+\right.$ cis-9 14:1) $\times 100$; a similar calculation was done for the remaining $\Delta^{9}$-desaturase indices reported in this table. 
Table 7. Effect of flaxseed oil (FSO) supplementation (0 vs. 3\% FSO) and corn grain [ground corn (GC) vs. cracked corn (CC)] particle size (PS) on plasma proportion of fatty acids (FA) in Jersey cows

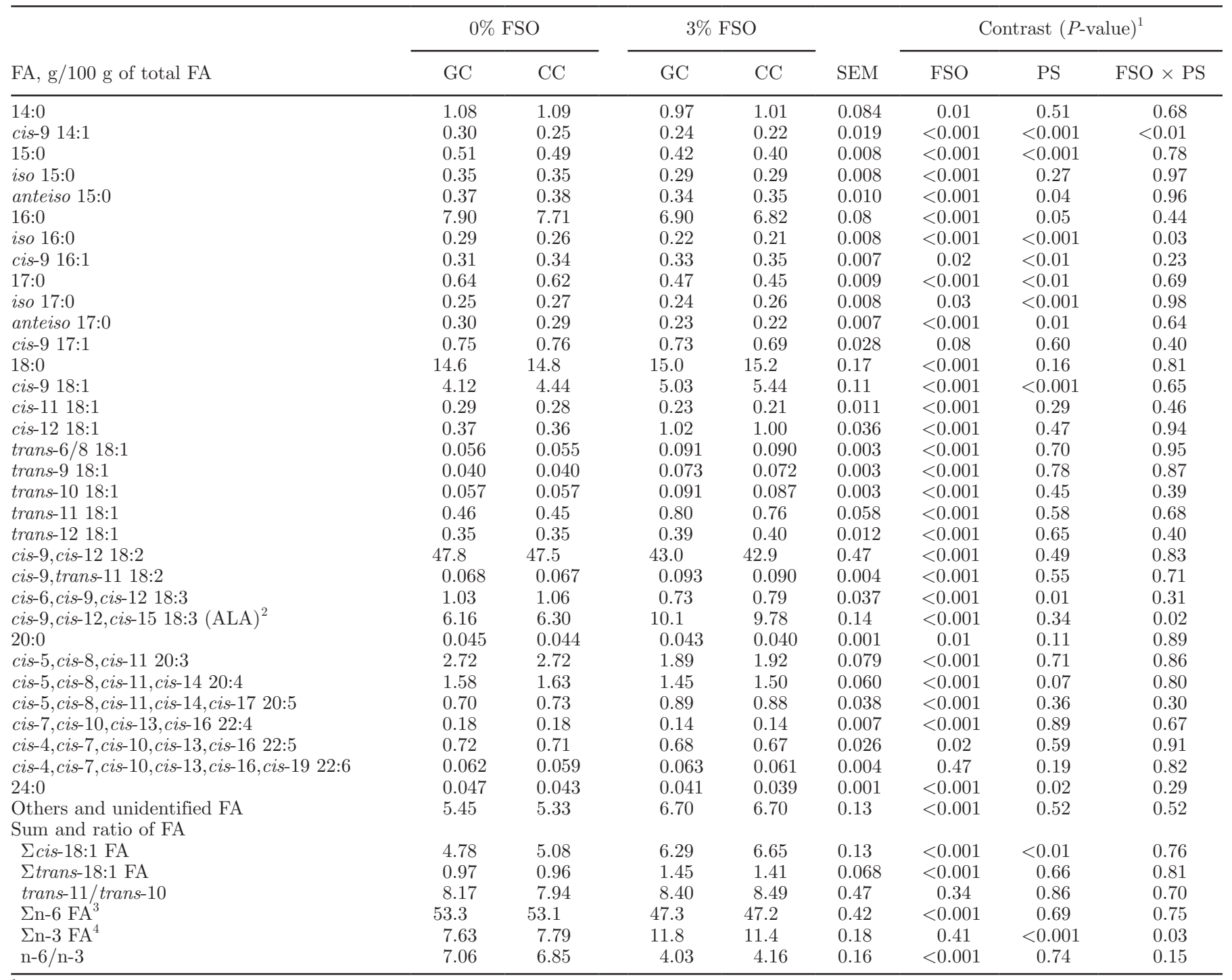

${ }^{1}$ Probability of FSO level main effect ( 0 vs. $3 \%$ FSO); probability of corn grain PS main effect (GC vs. CC); and probability of FSO level $\times$ corn grain PS interaction. Significance was declared at $P \leq 0.05$ and trends at $0.05<P \leq 0.10$.

${ }^{2} \mathrm{ALA}=\alpha$-linolenic acid.

${ }^{3} \mathrm{Nn}-6 \mathrm{FA}=$ cis-9,cis-12 18:2 + cis-6,cis-9,cis-12 18:3+ cis-8,cis-11,cis-14 20:3 + cis-5,cis-8,cis-11,cis-14 20:4.

${ }^{4} \mathrm{Vn}-3 \mathrm{FA}=$ cis-9,cis-12,cis-15 18:3 + cis-5,cis-8,cis-11,cis-14,cis-17 20:5 + cis-7,cis-10,cis-13,cis-16,cis-19 22:5 + cis-4,cis-7,cis-10,cis-13,cis16,cis-19 22:6.

$<0.01$ ) decreased in $3 \%$ FSO cows due to reduced milk fat and protein contents (Table 4). However, yields of milk SNF and TS were not affected because decreased milk fat and protein contents were offset by elevated milk yield when feeding $3 \%$ FSO. The concentration of MUN was lowest $(P<0.001$; Table 4$)$ in cows fed $3 \%$ FSO, likely as a result of lower dietary concentration of CP (Table 2) and $\mathrm{N}$ intake $(P<0.01$; Table 4$)$. The concentration of PUN was also lowest $(P<0.01)$ with feeding $3 \%$ FSO (Table 4).
Milk and Plasma FA Profile. With the exception of 4:0 and 18:0 proportions in milk, which increased $(P<0.001)$ with feeding $3 \%$ FSO, all remaining SFA significantly decreased in $3 \%$ FSO cows including $\Sigma$ branched-chain FA, $\Sigma<16 \mathrm{C} \mathrm{FA}$, and $\Sigma 16 \mathrm{C}$ FA (Table 5). In contrast, $\Sigma 18 \mathrm{C}$ FA increased $(P<0.001)$ in cows supplemented with 3\% FSO (Table 5). Decreased milk proportions of 6:0 to 16:0 and increased 18:0 are consistent with the inverse relationship between de novo synthesis of FA and intake of PUFA (Chilliard et al., 
Table 8. Effect of flaxseed oil (FSO) supplementation (0 vs. 3\% FSO) and corn grain [ground corn (GC) vs. cracked corn (CC)] particle size (PS) on apparent total-tract digestibility of nutrients and urinary excretion of nitrogenous metabolites in Jersey cows

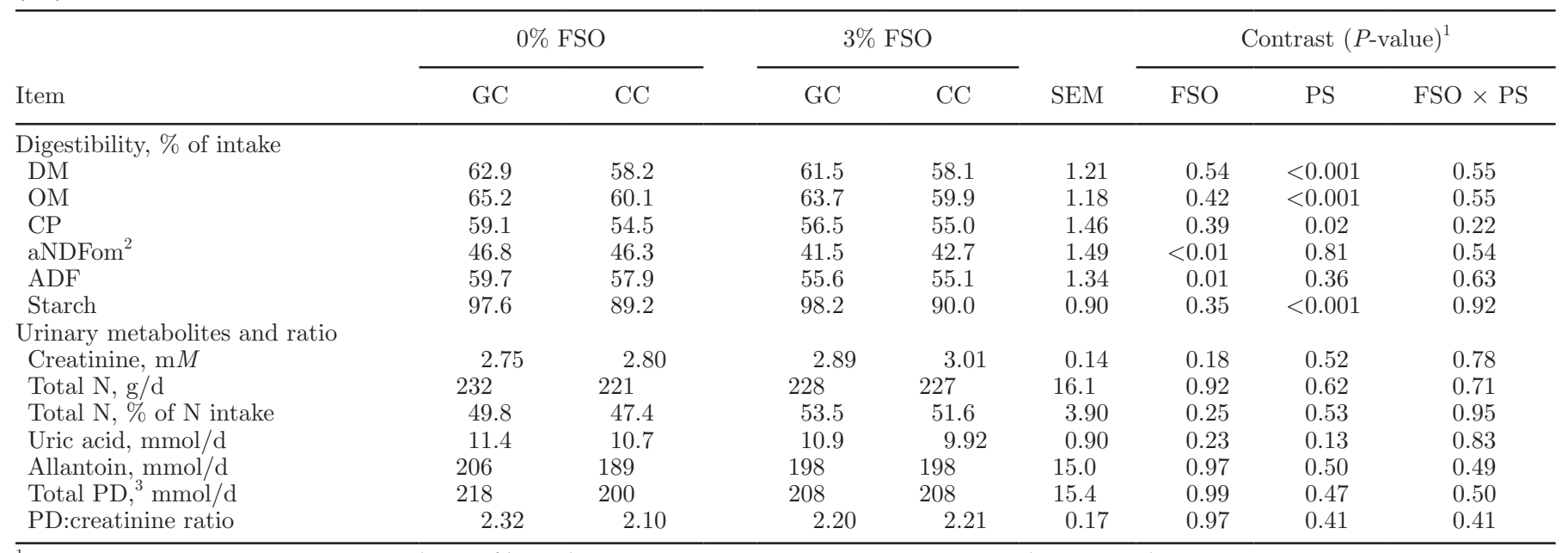

${ }^{1}$ Probability of FSO level main effect ( 0 vs. $3 \%$ FSO); probability of corn grain PS main effect (GC vs. CC); and probability of FSO level $\times$ corn grain PS interaction. Significance was declared at $P \leq 0.05$ and trends at $0.05<P \leq 0.10$.

${ }^{2}$ Determined with heat-stable amylase and sodium sulfite and expressed exclusive of residual ash.

${ }^{3}$ Total purine derivatives $(\mathrm{PD})=$ allantoin + uric acid.

2000). In fact, the plasma proportions of 14:0 $(P=$ $0.01)$ and 16:0 $(P<0.001)$ decreased, whereas plasma 18:0 increased $(P<0.001)$ in $3 \%$ FSO cows (Table 7$)$. The observed reductions of $\Sigma<16 \mathrm{C}$ FA and $\Sigma 16 \mathrm{C}$ FA in milk, and elevated milk $\Sigma 18 \mathrm{C} \mathrm{FA}$ in cows offered $3 \%$ FSO are in line with results from previous studies $(\mathrm{Bu}$ et al., 2007; Benchaar et al., 2012; Pi et al., 2016).

Decreased milk proportions of individual odd- and branched-chain FA (Table 5) suggest less duodenal flow of microbial protein as these FA are supplied primarily by ruminal microorganisms (Fievez et al., 2012) or that FSO supplementation depressed the growth of ruminal microbes that synthesize odd- and branched-chain FA. However, the urinary excretion of PD was not affected by $3 \%$ FSO supplementation (Table 8 ), suggesting no change in microbial protein synthesis in the rumen.

Except for the milk proportion of cis-11 18:1, which tended $(P=0.07)$ to decrease with feeding $3 \% \mathrm{FSO}$, all remaining UFA were significantly changed when comparing $0 \%$ versus $3 \%$ FSO diets (Table 6 ). Decreased milk proportions of cis-9 14:1, cis-9 16:1, and cis-9 17:1 in cows offered $3 \% \mathrm{FSO}$ are consistent with reduced $(P$ $\leq 0.05) \Delta^{9}$-desaturase indices for the cis-9 14:1/14:0, cis-9 16:1/16:0, and cis-9 17:1/17:0 pairs, respectively (Table 6 ). The milk proportions of cis-9 18:1, cis-12 18:1, and all trans-18:1 MUFA, as well as $\Sigma c i s-18: 1$ and $\Sigma$ trans-18:1, were greater in cows supplemented with $3 \%$ versus $0 \%$ FSO (Table 6 ), and are in agreement with the proportion of these FA in plasma (Table 7). These results may be explained by increased intake of cis-9 18:1 and ALA, which was 89 and $292 \%$ greater $(P$
$<0.001$ ), respectively, in $3 \%$ versus $0 \%$ FSO cows (data not shown).

The milk proportion of $c i s-9$, cis-12 18:2 was lower $(P$ $<0.001$ ) in 3\% versus $0 \%$ FSO cows (Table 6) despite an $18 \%$ increase in the intake of cis-9, cis-12 18:2 $(P<$ 0.001 ; data not shown), suggesting extensive ruminal biohydrogenation. In fact, Loor et al. (2004) reported that the ruminal biohydrogenation of cis-9,cis-12 18:2 increased by $12 \%$ in lactating dairy cows supplemented with FSO compared with the control diet. In the present study, the proportion of cis-9,cis-12 18:2 in plasma also decreased in 3\% FSO cows (Table 7) showing that less cis-9,cis-12 18:2 was available for uptake by the mammary gland. Others observed a linear decrease in the milk proportion of cis-9,cis-12 18:2 in cows fed incremental amounts of FSO $(0,2,3$, or $4 \%$ of the diet DM; Benchaar et al., 2012) or ground flaxseed (0, 5, 10 , or $15 \%$ of the diet DM; Resende et al., 2015), but no effect was observed with increasing dietary levels of extruded flaxseed (Ferlay et al., 2013). This discrepancy may be explained by decreased access of ruminal biohydrogenating microbiota to UFA as a result of the flaxseed extrusion process (Sterk et al., 2012).

Compared with 0\% FSO cows, feeding 3\% FSO increased $(P<0.001)$ the milk proportion of cis9,trans-11 $18: 2$ by $58 \%$ (Table 6 ), which was consistent with the increased proportions of trans-18:1 in milk $(+78 \%$; Table 6$)$ and plasma $(+73 \%$; Table 7$)$. The milk proportion of trans-11,cis-15 18:2 increased by $418 \%$ in $3 \%$ versus $0 \%$ FSO cows (Table 6), likely as a result of extensive ruminal biohydrogenation of 
ALA according to Harfoot and Hazlewood (1988). Loor et al. (2004) observed a 9.5\% increase in the ruminal biohydrogenation of ALA in cows supplemented with FSO compared with those fed the control diet. The $\Sigma$-6 FA $(P<0.01)$ and the n-6/n-3 ratio $(P=0.02)$ in milk were both lower in cows fed $3 \%$ rather than 0\% FSO (Table 6), which agrees with previous studies where FSO (Benchaar et al., 2012) or ground flaxseed (Resende et al., 2015) was fed to dairy cows.

Nutrient Digestibility and Purine Derivatives. Flaxseed oil supplementation did not affect the apparent total-tract digestibilities of DM, OM, CP, and starch, but decreased those of aNDFom $(P<0.01)$ and ADF $(P$ $=0.01$; Table 8 ), possibly as a result of PUFA toxicity to ruminal cellulolytic bacteria (Maia et al., 2007; Mao et al., 2010). Feeding FSO (Ueda et al., 2003; Martin et al., 2008) or incremental amounts of ground flaxseed (Resende et al., 2015) also depressed the total-tract digestibility of fiber in lactating dairy cows. Benchaar et al. (2015) reported that FSO + corn silage was more detrimental to total-tract fiber digestibility than red clover silage + FSO when fed to lactating dairy cows. However, the effect of FSO supplementation on fiber digestibility has not been consistent. Benchaar et al. (2012) reported no effect of incremental amounts of FSO on apparent total-tract digestibilities of NDF and ADF in lactating dairy cows. Furthermore, ruminal and total-tract digestibilities of NDF and ADF were not changed with feeding corn silage- or hay-based diets supplemented with incremental amounts of extruded flaxseed $(0,5,10$, or $15 \%$ of the diet DM) to lactating dairy cows (Martin et al., 2016).

The apparent total-tract digestibility of ADF was, on average, 13 percentage units greater than that of aNDFom (Table 8). This was unexpected particularly because fecal ADF output was likely overestimated, being not corrected for ash. Crocker et al. (1998) reported that the total-tract digestibilities of ash-free NDF were greater than that of NDF (inclusive of ash) in 2 experiments using lactating dairy cows, with same responses observed for digestibilities of ash-free $\mathrm{ADF}$ versus ADF (inclusive of ash). Thus, if the fecal output of ADF from the current study would have been corrected for ash, the difference between ADF and aNDFom digestibility could be even larger than 13 percentage units. Interestingly, in 2 studies conducted in our laboratory where iADF was also used as an intrinsic marker to estimate fecal output of nutrients, the differences between NDF and ADF total-tract digestibilities in Jersey cows offered mixed grass-legume baleage supplemented with incremental amounts of ground flaxseed $(+5.7$ percentage unit difference; Resende et al., 2015) or liquid molasses ( -2.1 percent- age unit difference; Ghedini et al., 2018) were within expected ranges. However, the difference in $\mathrm{ADF}$ and aNDFom total-tract digestibility (estimated via iADF) was of similar magnitude compared with that reported in the present experiment when Jersey cows fed mixed grass-legume baleage supplemented with soybean meal or okara meal (a co-product of soymilk production) in another study conducted in our laboratory (A. F. Brito, unpublished). Thus, it appears that differences were exacerbated when aNDFom rather than NDF was used despite the reasons behind these discrepancies remain to be elucidated. Crocker et al. (1998) concluded that the use of ash-free NDF and ADF resulted in more realistic and accurate digestibility estimates of fiber in the rumen and total tract. They also concluded that sample contamination by silica and other ash components may influence NDF and ADF concentrations if the fiber residues are not ashed before calculations of NDF and ADF digestibility (Crocker et al., 1998). Alternatively, it can be speculated that increased ADF versus NDF digestibility in the total tract may be caused by greater cellulose than hemicellulose digestibility.

Urinary excretion data from the present study should be interpreted cautiously because the creatinine excretion rate of $0.212 \mathrm{mmol} / \mathrm{kg}$ of $\mathrm{BW}$ reported by Chizzotti et al. (2008) was obtained using Holstein cows. However, Chizzotti et al. (2008) demonstrated that differences in milk yield did not affect the rate of urinary creatinine excretion $/ \mathrm{kg}$ of BW. They also stated that adult cattle have less variation in body composition and, therefore, creatinine excretion as a function of BW becomes less variable. Supplementation with 3\% FSO did not affect the urinary excretion of $\mathrm{N}$, uric acid, allantoin, and $\mathrm{PD}$, as well as the excretion of $\mathrm{N}$ in urine as a proportion of $\mathrm{N}$ intake (Table 8). Ueda et al. (2003) reported an interaction between FSO supplementation (3\% of the diet DM) and forage-to-concentrate ratio for the duodenal flow of bacterial $\mathrm{N}$; whereas cows fed the high-forage diet supplemented with FSO showed the lowest duodenal flow of bacterial N, those fed the highconcentrate diet and FSO had the greatest. Moreover, Gonthier et al. (2004) observed that the duodenal flow of bacterial $\mathrm{N}$ decreased by $25 \%$ in cows fed, on average, $12.6 \%$ of the diet DM as flaxseed (raw, micronized, or extruded) compared with the control diet. These discrepancies in microbial protein synthesis measured directly using purines as the bacterial marker (Ueda et al., 2003; Gonthier et al., 2004) or estimated indirectly via urinary excretion of PD (present study) may be associated with differences in the composition and proportion of dietary ingredients and whether flaxseed was offered as oil or grain. 


\section{Main Effect of Corn Grain Particle Size}

Production and Milk Composition. Intake of DM, milk yield, concentration and yield of milk components, feed and milk $\mathrm{N}$ efficiencies, MUN, and PUN were not affected by corn grain PS (Table 4). Knowlton et al. (1996) reported no effect of corn grain PS on DMI and yield of milk fat in dairy cows fed GC versus CC. In contrast, milk yield tended to increase and concentration and yield of milk protein increased with feeding GC (Knowlton et al., 1996). Fredin et al. (2015) observed no effects of corn grain PS on DMI, milk yield, and concentrations and yields of milk components in dairy cows fed normal $(26.5 \%)$ or reduced $(18.2 \%)$ starch diets consisting of finely or coarsely ground corn. The difference in mean PS between GC and CC averaged 2,438 and 1,467 $\mu \mathrm{m}$ in Knowlton et al. (1996) and in the present study, respectively, and $718 \mu \mathrm{m}$ between finely versus coarsely ground corn in Fredin et al. (2015). Thus, the greater difference in corn grain PS reported by Knowlton et al. (1996) may explain the observed discrepancies in production and milk composition. However, Ferraretto et al. (2013) reported, in a meta-analysis, no differences in DMI, milk yield, concentration and yield of milk components, and feed efficiency in dairy cows when the mean PS of dry GC, CC, and rolled corn differed by a minimum of 500 $\mu \mathrm{m}$ to a maximum of $3,500 \mu \mathrm{m}$.

Milk and Plasma FA Profile. The milk proportions of 11:0, 12:0, 14:0, iso 14:0, 15:0, anteiso 15:0, 16:0, 17:0, and anteiso 17:0 were significantly greater in cows fed GC versus CC (Table 5). In contrast, the proportion of 18:0 in milk was greatest in cows fed CC (Table 5). The $\Sigma$ branched-chain FA, $\Sigma<16 \mathrm{C} \mathrm{FA,}$ and $\Sigma 16 \mathrm{C}$ FA were also greater in GC than $\mathrm{CC}$ cows, whereas $\Sigma 18 \mathrm{C}$ was increased with feeding CC (Table 5). Elevated milk proportions of odd- and branchedchain FA in cows fed GC are suggestive of enhanced microbial protein synthesis in the rumen (Fievez et al., 2012) or that GC stimulated the growth of ruminal microbes that synthesize odd- and branched-chain FA. It is important to note, however, that the urinary excretion of PD was not affected by corn grain PS in the present study (Table 8). Except for anteiso 15:0 and iso 17:0, the proportions of 15:0, 17:0, and anteiso 17:0 in milk followed the same patterns observed for plasma, with cows fed GC showing greater $(P \leq 0.01)$ values than those fed CC (Table 7 ). The discrepancy between milk and plasma proportions for anteiso 15:0 and iso 17:0 suggests endogenous synthesis of these branched-chain FA (Vlaeminck et al., 2015). Similar to milk 16:0, the proportion of 16:0 in plasma was lower $(P=0.05)$ in GC than CC cows (Table 7). Intake of $16: 0$ was $7 \%$ lower $(P<0.01$; data not shown $)$ in GC compared with CC treatments, which is consistent with decreased 16:0 in plasma and milk because this FA can be originated from the diet or de novo synthesis in the mammary gland. Although the milk proportion of 18:0 increased $(P<0.01)$ in cows fed CC (Table 5), corn grain PS did not affect the proportion of 18:0 in plasma (Table 7). Intake of 18:0 averaged $27 \mathrm{~g} / \mathrm{d}$ and was not affected $(P=0.12)$ by corn PS (data not shown), which is consistent with plasma 18:0. The mammary gland extracts 18:0 from blood and intake of 18:0 was not affected by corn PS, so the reason for this small, but significant, difference in milk 18:0 between CC and GG is not conclusive.

The milk proportion of cis-9 18:1 was lower $(P<$ 0.001) in GC than CC cows (Table 6), with this result not explained by intake of cis-9 18:1 (data not shown) or $\Delta^{9}$-desaturase index (cis-9 18:1/18:0 pair; Table 6) as these 2 variables were not affected by corn PS. The milk proportion of cis-9,cis-12 18:2 was greater $(P<$ 0.01 ) in GC than $\mathrm{CC}$ cows (Table 6). Intake of cis9,cis-12 18:2 decreased $(-21 \mathrm{~g} / \mathrm{d} ; P<0.001$; data not shown) with feeding GC, whereas plasma cis-9, cis-12 18:2 was not affected by corn PS (Table 7). These results suggest less biohydrogenation of cis-9,cis-12 18:2 with reduced corn PS, which is in line with Lascano et al. (2016) who reported decreased biohydrogenation of cis-9, cis-12 18:2 in continuous culture fermentors fed corn grain varying from low to high starch degradability. The $\Sigma$ cis-18:1 FA followed the proportion of cis-9 18:1 in milk and was lower $(P<0.001)$ in GC than CC cows, whereas $\Sigma$ n-6 FA followed the proportion of cis-9,cis-12 18:2 in milk and increased in cows fed GC than in those fed CC (Table 6).

Nutrient Digestibility and Purine Derivatives. The apparent total-tract digestibilities of DM, OM, CP, and starch were greater $(P \leq 0.02)$ in cows fed GC than $\mathrm{CC}$, but the largest difference was observed for starch digestibility, which improved by 8 percentage units (Table 8). This improvement in starch digestibility is likely explained by increased surface area of finer compared with coarser particles, thereby facilitating ruminal microbiota and host enzymatic digestion according to Nocek and Tamminga (1991) and Huntington (1997). In fact, the surface area of GC $\left(141 \mathrm{~cm}^{2} / \mathrm{g}\right)$ was $385 \%$ greater than that of CC $\left(29.9 \mathrm{~cm}^{2} / \mathrm{g}\right)$ as shown in Table 3. Knowlton et al. (1996) also reported an increase $(+7$ percentage units) in the apparent total-tract digestibility of starch in cows fed GC versus CC. Fredin et al. (2015) observed a significant starch level $\times$ corn PS interaction, with the difference in total-tract digestibility of starch between finely and coarsely ground corn being greater in cows fed the normal starch diet $(+7$ percentage units) than the reduced starch diet $(+2.1$ percentage units). The fate of this additional digestible energy 
coming from starch in cows fed the normal starch diet was independent of BW, BCS, and milk yield, which did not differ significantly across treatments in the study of Fredin et al. (2015). However, a trend for an interaction between starch level and corn PS was observed for milk fat yield, thereby suggesting that additional energy from increased starch digestibility may have been used to produce milk fat in their experiment (Fredin et al., 2015). In the meta-analysis of Ferraretto et al. (2013), the apparent total-tract digestibilities of DM, OM, and starch decreased as dry corn grain PS increased without an effect on NDF digestibility, which corroborate our results.

The urinary excretion of nitrogenous compounds, including PD, was not affected by corn grain PS (Table 8). Likewise, San Emeterio et al. (2000) observed no change in the urinary allantoin-to-creatinine ratio in lactating dairy cows fed finely or coarsely ground dry shelled corn, suggesting similar microbial protein synthesis between treatments. Knowlton et al. (1998) reported no difference in the duodenal flow of bacterial $\mathrm{N}$ in lactating dairy cows fed GC or rolled corn with mean PS of 618 and 1,725 $\mu \mathrm{m}$, respectively. Similarly, the omasal flow of bacterial NAN was not affected by corn grain PS (finely vs. coarsely ground) with feeding normal or reduced starch diets to lactating dairy cows (Fredin et al., 2015). Even though is conceivable that more fermentable energy would be available for microbial use in the rumen when feeding finely rather than coarsely ground corn, urinary excretion of PD (current study) or microbial protein synthesis measured directly using purines (Knowlton et al., 1998) or ${ }^{15} \mathrm{~N}$ (Fredin et al., 2015) as bacterial markers were not affected, possibly due to tradeoffs among ruminal $\mathrm{pH}$, fiber digestibility, and microbiota growth.

\section{CONCLUSIONS}

Yields of milk and milk fat and lactose, as well as feed efficiency, were improved in cows fed $3 \%$ FSO, which is consistent with our first hypothesis that milk and milk components would respond to increased energy intake. Our second hypothesis that corn grain differing in PS would increase the proportion of trans FA intermediates in milk fat and improve milk $\mathrm{N}$ efficiency in cows fed GC versus CC was rejected. A significant FSO $\times$ corn grain PS interaction was observed for milk ALA with the greatest proportion of this FA found in cows fed $3 \%$ FSO + GC, which is consistent with our third hypothesis. However, no FSO $\times$ corn grain PS interactions were observed for production and nutrient digestibility. Overall, results of the current study are more directly applicable to dairy systems in which cows have access to the outdoors during the winter months (e.g., organic-certified farms) and are fed low starch, mixed grass-legume baleage-based diets. Further research is needed to investigate the effect of potential interactions between FSO and corn grain PS on production, nutrient digestibility, and milk FA profile in dairy cows fed high starch diets or diets differing in forage-to-concentrate ratios or conserved forage sources.

\section{ACKNOWLEDGMENTS}

Partial funding was provided by the New Hampshire Agricultural Experiment Station (Durham, NH; Scientific Contribution Number 2761). This work was further supported by the USDA-National Institute of Food and Agriculture-Organic Agriculture Research and Extension Initiative (Project Number NHW-2011-01950; Project Accession Number 226410) and Hatch Multistate NC-2042 (Project Number NH00616-R; Project Accession Number 1001855). Gratitude is extended to $\mathrm{CNPq}$ (Brasília, DF, Brazil) and CAPES (Brasília, DF, Brazil) for scholarships provided to co-authors D. C. Moura and J. G. B. Galvão Jr., respectively. The authors also thank the undergraduate student James Black (University of New Hampshire, Durham) for support during feeding and samples collection, as well as the graduate student Luiz Henrique Pereira Silva for conducting laboratory analyses (Universidade Federal de Viçosa, Viçosa, MG, Brazil). Appreciation is extended to the University of New Hampshire BurleyDemeritt Organic Dairy Research Farm manager Nicole Guindon and her staff for animal care and overall research support.

\section{REFERENCES}

AOAC. 1990. Official Methods of Analysis. 15th ed. AOAC, Arlington, VA.

AOAC International. 2016. Official Methods of Analysis, 20th ed. AOAC International, Gaithersburg, MD.

Baker, S., and T. Herrman. 2002. Evaluating particle size. MF-2051. Kansas State Univ. Coop Ext. Serv., Manhattan, KS. Accessed Sep. 23, 2017. https://www.bookstore.ksre.ksu.edu/pubs/MF2051 .pdf.

Baumgard, L. H., E. Matitashvili, B. A. Corl, D. A. Dwyer, and D. E. Bauman. 2002. trans-10, cis-12 conjugated linoleic acid decreases lipogenic rates and expression of genes involved in milk lipid synthesis in dairy cows. J. Dairy Sci. 85:2155-2163.

Benchaar, C., F. Hassanat, R. Martineau, and R. Gervais. 2015. Linseed oil supplementation to dairy cows fed diets based on red clover silage or corn silage: Effects on methane production, rumen fermentation, nutrient digestibility, $\mathrm{N}$ balance, and milk production. J. Dairy Sci. 98:7993-8008.

Benchaar, C., T. A. McAllister, H. V. Petit, and P. Y. Chouinard. 2014. Whole flax seed and flax oil supplementation of dairy cows fed high-forage or high-concentrate diets: Effects on digestion, ruminal fermentation characteristics, protozoal populations and milk fatty acid profile. Anim. Feed Sci. Technol. 198:117-129.

Benchaar, C., G. Romero-Pérez, P. Y. Chouinard, F. Hassanat, M. Eugene, H. V. Petit, and C. Côrtes. 2012. Supplementation of increasing amounts of linseed oil to dairy cows fed total mixed 
rations: Effects on digestion, ruminal fermentation characteristics, protozoal populations, and milk fatty acid composition. J. Dairy Sci. 95:4578-4590.

Bu, D. P., J. Q. Wang, T. R. Dhiman, and S. J. Liu. 2007. Effectiveness of oils rich in linoleic and linolenic acids to enhance conjugated linoleic acid in milk from dairy cows. J. Dairy Sci. 90:998-1007.

Chen, X. B., Y. K. Chen, M. F. Franklin, E. R. Ørskov, and W. J. Shand. 1992. The effect of feed intake and body weight on purine derivative excretion and microbial protein supply in sheep. J. Anim. Sci. 70:1534-1542.

Chilliard, Y., A. Ferlay, R. Mansbridge, and M. Doreau. 2000. Ruminant milk fat plasticity: Nutritional control of saturated, polyunsaturated, trans and conjugated fatty acids. Ann. Zootech. 49:181-205.

Chilliard, Y., C. Martin, J. Rouel, and M. Doreau. 2009. Milk fatty acids in dairy cows fed whole crude linseed, extruded linseed, or linseed oil, and their relationship with methane output. J. Dairy Sci. 92:5199-5211.

Chizzotti, M. L., S. C. Valadares Filho, R. F. D. Valadares, F. H. M. Chizzotti, and L. O. Tedeschi. 2008. Determination of creatinine excretion and evaluation of spot urine sampling in Holstein cattle. Livest. Sci. 113:218-225.

Coblentz, W. K., K. P. Coffey, and E. A. Chow. 2016. Storage characteristics, nutritive value, and fermentation characteristics of alfalfa packaged in large-round bales and wrapped in stretch film after extended time delays. J. Dairy Sci. 99:3497-3511.

Cochran, R. C., D. C. Adams, J. D. Wallace, and M. L. Galyean. 1986. Predicting digestibility of different diets with internal markers: Evaluation of four potential markers. J. Anim. Sci. 63:1476-1483.

Crocker, L. M., E. J. DePeters, J. G. Fadel, S. E. Essex, H. PerezMonti, and S. J. Taylor. 1998. Ash content of detergent fibers in feeds, digesta, and feces and its relevance in fiber digestibility calculations. J. Dairy Sci. 81:1010-1014.

Ferlay, A., M. Doreau, C. Martin, and Y. Chilliard. 2013. Effects of incremental amounts of extruded linseed on the milk fatty acid composition of dairy cows receiving hay or corn silage. J. Dairy Sci. 96:6577-6595

Ferraretto, L. F., P. M. Crump, and R. D. Shaver. 2013. Effect of cereal grain type and corn grain harvesting and processing methods on intake, digestion, and milk production by dairy cows through a meta-analysis. J. Dairy Sci. 96:533-550.

Fievez, V., E. Colman, J. M. Castro-Montoya, I. Stefanov, and B. Vlaeminck. 2012. Milk odd- and branched-chain fatty acids as biomarkers of rumen function-An update. Anim. Feed Sci. Technol. 172:51-65.

Fredin, S. M., L. F. Ferraretto, M. S. Akins, S. J. Bertics, and R. D. Shaver. 2015. Effects of corn-based diet starch content and corn particle size on lactation performance, digestibility, and bacterial protein flow in dairy cows. J. Dairy Sci. 98:541-553.

Gaines, W. L., and F. A. Davidson. 1923. Relation between percentage fat content and yield of milk. Bull. 245. Illinois Agric. Expt. Sta., Urbana, IL.

Ghedini, C. P., D. C. Moura, R. A. V. Santana, A. S. Oliveira, and A. F. Brito. 2018. Replacing ground corn with incremental amounts of liquid molasses does not change milk enterolactone but decreases production in dairy cows fed flaxseed meal. J. Dairy Sci. 101:2096-2109. https://doi.org/10.3168/jds.2017-13689.

Glasser, F., A. Ferlay, and Y. Chilliard. 2008. Oilseed lipid supplements and fatty acid composition of cow milk: A meta-analysis. J. Dairy Sci. 91:4687-4703.

Gonthier, C., A. F. Mustafa, R. Berthiaume, H. V. Petit, R. Martineau, and D. R. Ouellet. 2004. Effects of feeding micronized and extruded flaxseed on ruminal fermentation and nutrient utilization by dairy cows. J. Dairy Sci. 87:1854-1863.

Griinari, J. M., B. A. Corl, S. H. Lacy, P. Y. Chouinard, K. V. V. Nurmela, and D. E. Bauman. 2000. Conjugated linoleic acid is synthesized endogenously in lactating dairy cows by $\Delta^{9}$-desaturase. J. Nutr. 130:2285-2291.

Hafla, A. N., K. J. Soder, A. F. Brito, R. Kersbergen, A. F. Benson, H. M. Darby, M. D. Rubano, and S. F. Reis. 2016. Case study: Feeding strategy and pasture quality relative to nutrient requirements of dairy cows in the northeastern United States. Prof. Anim. Sci $32: 523-530$.

Hall, M. B., W. H. Hoover, J. P. Jennings, and T. K. M. Webster. 1999. A method for partitioning neutral detergent soluble carbohydrates. J. Sci. Food Agric. 79:2079-2086.

Hardie, C. A., M. Wattiaux, M. Dutreuil, R. Gildersleeve, N. S. Keuler, and V. E. Cabrera. 2014. Feeding strategies on certified organic dairy farms in Wisconsin and their effect on milk production and income over feed costs. J. Dairy Sci. 97:4612-4623.

Harfoot, C. G., and G. P. Hazlewood. 1988. Lipid metabolism in the rumen. Pages 285-322 in The Rumen Microbial Ecosystem. P. N. Hobson, ed. Elsevier Applied Science Publishers, London, UK.

Huhtanen, P., K. Kaustell, S. Jaakkola, E. M. Aitchison, M. Gill, and M. Dhanoa. 1994. The use of internal markers to predict total digestibility and duodenal flow of nutrients in cattle given six different diets. Anim. Feed Sci. Technol. 48:211-227.

Huntington, G. B. 1997. Starch utilization by ruminants: From basics to the bunk. J. Anim. Sci. 75:852-867.

Ipharraguerre, I. R., and J. H. Clark. 2003. Soyhulls as an alternative feed for lactating dairy cows: A Review. J. Dairy Sci. 86:1052-1073.

Kim, B. G., and H. H. Stein. 2009. A spreadsheet program for making a balanced Latin square design. Rev. Colomb. Cienc. Pecu. $22: 591-596$.

Knowlton, K. F., M. S. Allen, and P. S. Erickson. 1996. Lasalocid and particle size of corn grain for dairy cows in early lactation 1 . Effect on performance, serum metabolites, and nutrient digestibility. J. Dairy Sci. 79:557-564.

Knowlton, K. F., B. P. Glenn, and R. A. Erdman. 1998. Performance, ruminal fermentation, and site of starch digestion in early lactation cows fed corn grain harvested and processed differently. J. Dairy Sci. 81:1972-1984.

Lascano, G. J., M. Alende, L. E. Koch, and T. C. Jenkins. 2016. Changes in fermentation and biohydrogenation intermediates in continuous cultures fed low and high levels of fat with increasing rates of starch degradability. J. Dairy Sci. 99:6334-6341.

Loor, J. J., A. Ferlay, A. Ollier, M. Doreau, and Y. Chilliard. 2005. Relationship among trans and conjugated fatty acids and bovine milk fat yield due to dietary concentrate and linseed oil. J. Dairy Sci. 88:726-740

Loor, J. J., K. Ueda, A. Ferlay, Y. Chilliard, and M. Doreau. 2004 Biohydrogenation, duodenal flow, and intestinal digestibility of trans fatty acids and conjugated linoleic acids in response to dietary forage:concentrate ratio and linseed oil in dairy cows. J. Dairy Sci. 87:2472-2485.

Maia, M. R. G., L. C. Chaudhary, L. Figueres, and R. J. Wallace 2007. Metabolism of polyunsaturated fatty acids and their toxicity to the microflora of the rumen. Antonie van Leeuwenhoek 91:303-314.

Mao, H. L., J. K. Wang, Y. Y. Zhou, and J. X. Liu. 2010. Effects of addition of tea saponins and soybean oil on methane production, fermentation and microbial population in the rumen of growing lambs. Livest. Sci. 129:56-62.

Martin, C., A. Ferlay, P. Mosoni, Y. Rochette, Y. Chilliard, and M. Doreau. 2016. Increasing linseed supply in dairy cow diets based on hay or corn silage: Effect on enteric methane emission, rumen microbial fermentation, and digestion. J. Dairy Sci. 99:3445-3456.

Martin, C., J. Rouel, J. P. Jouany, M. Doreau, and Y. Chilliard. 2008. Methane output and diet digestibility in response to feeding dairy cows crude linseed, extruded linseed, or linseed oil. J. Anim. Sci. $86: 2642-2650$.

Meignan, T., C. Lechartier, G. Chesneau, and N. Bareille. 2017. Effects of feeding extruded linseed on production performance and milk fatty acid profile in dairy cows: A meta-analysis. J. Dairy Sci. 100:4394-4408.

Neveu, C., B. Baurhoo, and A. Mustafa. 2014. Effect of feeding extruded flaxseed with different grains on the performance of dairy cows and milk fatty acid profile. J. Dairy Sci. 97:1543-1551.

Nocek, J. E., and S. Tamminga. 1991. Site of digestion of starch in the gastrointestinal tract of dairy cows and its effect on milk yield and composition. J. Dairy Sci. 74:3598-3629. 
NRC. 2001. Nutrient Requirements of Dairy Cattle. 7th rev. ed. Natl. Acad. Sci., Washington, DC.

Petit, H. V. 2010. Milk yield and milk composition of dairy cows fed flaxseed: A review. Can. J. Anim. Sci. 90:115-127.

Pi, Y., S. T. Gao, L. Ma, Y. X. Zhu, J. Q. Wang, J. M. Zhang, J. C. $\mathrm{Xu}$, and D. P. Bu. 2016. Effectiveness of rubber seed oil and flaxseed oil to enhance the $\alpha$-linolenic acid content in milk from dairy cows. J. Dairy Sci. 99:5719-5730.

Resende, T. L., J. Kraft, K. J. Soder, A. B. D. Pereira, D. E. Woitschach, R. B. Reis, and A. F. Brito. 2015. Incremental amounts of ground flaxseed decrease milk yield but increase n- 3 fatty acids and conjugated linoleic acids in dairy cows fed high-forage diets. J. Dairy Sci. 98:4785-4799.

Rico, D. E., and K. J. Harvatine. 2013. Induction of and recovery from milk fat depression occurs progressively in dairy cows switched between diets that differ in fiber and oil concentration. J. Dairy Sci. 96:6621-6630.

Rosenthal, H. L. 1955. Determination of urea in blood and urine with diacetyl monoxime. Anal. Chem. 27:1980-1982.

San Emeterio, F., R. B. Reis, W. E. Campos, and L. D. Satter. 2000. Effect of coarse or fine grinding on utilization of dry or ensiled corn by lactating dairy cows. J. Dairy Sci. 83:2839-2848.

Shingfield, K. J., A. Sæbø, P.-C. Sæbø, V. Toivonen, and J. M. Griinari. 2009. Effect of abomasal infusions of a mixture of octadec- enoic acids on milk fat synthesis in lactating cows. J. Dairy Sci. 92:4317-4329.

Sterk, A., B. Vlaeminck, A. M. van Vuuren, W. H. Hendriks, and J. Dijkstra. 2012. Effects of feeding different linseed sources on omasal fatty acid flows and fatty acid profiles of plasma and milk fat in lactating dairy cows. J. Dairy Sci. 95:3149-3165.

Sukhija, P. S., and D. L. Palmquist. 1988. Rapid method for determination of total fatty acid content and composition of feedstuffs and feces. J. Agric. Food Chem. 36:1202-1206.

Tyrrell, H. F., and J. T. Reid. 1965. Prediction of the energy value of cow's milk. J. Dairy Sci. 48:1215-1223.

Ueda, K., A. Ferlay, J. Chabrot, J. J. Loor, Y. Chilliard, and M. Doreau. 2003. Effect of linseed oil supplementation on ruminal digestion in dairy cows fed diets with different forage:concentrate ratios. J. Dairy Sci. 86:3999-4007.

Van Soest, P. J., J. B. Robertson, and B. A. Lewis. 1991. Methods for dietary fiber, neutral detergent fiber, and nonstarch polysaccharides in relation to animal nutrition. J. Dairy Sci. 74:3583-3597.

Vlaeminck, B., R. Gervais, M. M. Rahman, F. Gadeyne, M. Gorniak, M. Doreau, and V. Fievez. 2015. Postruminal synthesis modifies the odd- and branched-chain fatty acid profile from the duodenum to milk. J. Dairy Sci. 98:4829-4840.

Williams, E. J. 1949. Experimental designs balanced for the estimation of residual effects of treatments. Aust. J. Sci. Res. A 2:149-168. 